\title{
Impacts of the combined exposure to seawater acidification and arsenic on the proteome of Crassostrea angulata and Crassostrea gigas
}

\author{
Anthony Moreira ${ }^{a}$, Etelvina Figueira ${ }^{a}$, Nélia C. Mestre ${ }^{b}$, Denise Schrama ${ }^{c}$, \\ Amadeu M.V.M. Soares ${ }^{\mathrm{a}}$, Rosa Freitas ${ }^{\mathrm{a}, *}$, Maria João Bebianno ${ }^{\mathrm{b}}$ \\ a Departamento de Biologia \& CESAM, Universidade de Aveiro, Campus Universitário de Santiago, Aveiro, Portugal \\ ${ }^{\mathrm{b}}$ CIMA, Universidade do Algarve, Campus de Gambelas, Faro, Portugal \\ ${ }^{\mathrm{c}}$ CCMAR, Universidade do Algarve, Campus de Gambelas, Faro, Portugal
}

\section{A R T I C L E I N F O}

\section{Keywords:}

Oyster

Proteomics

Crassostrea

Arsenic

Global change

\begin{abstract}
A B S T R A C T
Proteomic analysis was performed to compare the effects of Arsenic (As), seawater acidification (Low pH) and the combination of both stressors (Low $\mathrm{pH}+\mathrm{As}$ ) on Crassostrea angulata and Crassostrea gigas juveniles in the context of global environmental change. This study aimed to elucidate if two closely related Crassostrea species respond similarly to these environmental stressors, considering both single and combined exposures, to infer if the simultaneous exposure to both stressors induced a differentiated response. Identification of the most important differentially expressed proteins between conditions revealed marked differences in the response of each species towards single and combined exposures, evidencing species-related differences towards each experimental condition. Moreover, protein alterations observed in the combined exposure (Low $\mathrm{pH}+\mathrm{As}$ ) were substantially different from those observed in single exposures. Identified proteins and their putative biological functions revealed an array of modes of action in each condition. Among the most important, those involved in cellular structure (Actin, Atlastin, Severin, Gelsolin, Coronin) and extracellular matrix modulation (Ependymin, Tight junction ZO-1, Neprilysin) were strongly regulated, although in different exposure conditions and species. Data also revealed differences regarding metabolic modulation capacity (ATP $\beta$, Enolase, Aconitate hydratase) and oxidative stress response (Aldehyde dehydrogenase, Lactoylglutathione, Retinal dehydrogenase) of each species, which also depended on single or combined exposures, illustrating a different response capacity of both oyster species to the presence of multiple stressors. Interestingly, alterations of piRNA abundance in $C$. angulata suggested genome reconfiguration in response to multiple stressors, likely an important mode of action related to adaptive evolution mechanisms previously unknown to oyster species, which requires further investigation. The present findings provide a deeper insight into the complexity of $C$. angulata and $C$. gigas responses to environmental stress at the proteome level, evidencing different capacities to endure abiotic changes, with relevance regarding the ecophysiological fitness of each species and competitive advantages in a changing environment.
\end{abstract}

\section{Introduction}

The uptake of carbon dioxide $\left(\mathrm{CO}_{2}\right)$ by the world's ocean surface waters is altering global seawater chemistry. Dissolution of $\mathrm{CO}_{2}$ in seawater leads to a net increase of carbonic acid $\left(\mathrm{H}_{2} \mathrm{CO}_{3}\right)$, hydrogen $\left(\mathrm{H}^{+}\right)$and bicarbonate $\left(\mathrm{HCO}_{3}{ }^{-}\right)$ion concentrations, thus increasing seawater acidity $\left(\mathrm{pH}=-\log \left[\mathrm{H}^{+}\right]\right)$. These reactions are followed by a decrease of carbonate ion $\left(\mathrm{CO}_{3}{ }^{2-}\right)$ concentration and lower saturation states of aragonite $(\Omega \mathrm{Ar})$ and calcite $(\Omega \mathrm{Ca})$. In short, this physico-chemical phenomenon is termed ocean acidification (OA) (Fabry et al., 2008). The International Panel for Climate Change (IPCC) projected $p \mathrm{CO}_{2}$ levels in surface oceanic waters to reach between 490 and 1370 $\mu$ atm ( 0.06 to $0.32 \mathrm{pH}$ unit drop), depending on the atmospheric emission scenario (IPCC, 2014), while other authors suggest that $\mathrm{pH}$ in the ocean will decrease up to 0.5 units by year 2100 (Caldeira and Wickett, 2005; Raven et al., 2005). However, the impacts of OA are expected to be amplified in nearshore habitats (estuaries, bays, mangroves), where diel and seasonal $\mathrm{pH}$ and $p \mathrm{CO}_{2}$ fluctuations are common features (Baumann and Smith, 2018; Miller et al., 2009; Tomanek et al., 2011). In such ecosystems, OA may further exacerbate the higher amplitude of $\mathrm{pH}$ fluctuations (Ringwood and Keppler, 2002), and increased $p \mathrm{CO}_{2}$ levels (Melzner et al., 2012) compared to oceanic waters,

\footnotetext{
* Corresponding author at: Departamento de Biologia, Universidade de Aveiro, Campus Universitário de Santiago, $3810-193$ Aveiro, Portugal.

E-mail address: rosafreitas@ua.pt (R. Freitas).
} 
thus presenting increased environmental stress to inhabiting biota

Nonetheless, changes in seawater physico-chemical characteristics due to increased $p \mathrm{CO}_{2}$ in seawater are not occurring in isolation, given the concurrent threat of other stressors, especially considering anthropogenic pollution (Roberts et al., 2013). In fact, recent research demonstrated that OA may alter the bioavailability of inorganic contaminants such as metal(loid)s (Zeng et al., 2015), by increasing the relative amount of free metal form, given that $\mathrm{pH}$ influences the adsorption properties of these elements with dissolved organic matter, carbonate ion, sulphide, and iron (oxy)hydroxide minerals. OA is therefore expected to increase metal bioavailability, thus potentially increasing element uptake by organisms (Martín-Torre et al., 2017). Such interactions become most relevant in highly dynamic ecosystems such as estuaries, which function as major sinks for contaminants. The contaminants accumulate particularly in the sediment compartment, but tend to be remobilized into the liquid phase during sediment resuspension events (e.g. waves, storms, tidal currents, bioturbation, dredging), during which contaminants concentrations may exponentially increase in the water column (Harley et al., 2006; Mamindy-Pajany et al., 2013; Robins et al., 2016). Arsenic (As) is a highly toxic metalloid known to accumulate in estuarine sediments (e.g. $24.7 \mathrm{mg} \mathrm{kg}^{-1}$ d.w.; Costa et al., 2008) and to re-enter the water phase during (bio)turbation events (De Gieter et al., 2005; Masson et al., 2007; Mamindy-Pajany et al., 2013) (e.g. $260 \mathrm{mg} \mathrm{kg}^{-1}$ in suspended particulate matter; Ereira et al., 2015), as well as during extreme weather events (Henke, 2009; Galloway et al., 2017).

These issues raise the question on the impacts of increased As exposure concentrations to biota, and to its toxicology when interacting with climate change-related phenomena like OA.

The current understanding of the complex interaction of climate change-associated stressors like OA and contaminants such as As is still in its infancy, and the need to improve the predictive power on the impacts of hazardous substances in aquatic ecosystems is becoming increasingly urgent considering the eminent threat of climate change (Niinemets et al., 2017). Accordingly, the combined effects of multiple stressors on marine organisms is a growing field of research, and the interaction between OA and contaminants has gained increasing attention (Freitas et al., 2016; Nardi et al., 2017, among others).

The sessile nature, calcification and accumulation capacity have made marine bivalve species preferential models to study the interactive effects of $\mathrm{OA}$ and pollutants. Among marine bivalves the Ostreidae family includes some of the most extensively studied species (Tomanek et al., 2011; Ivanina and Sokolova, 2013; Matoo et al., 2013; Moreira et al., 2016). Crassostrea gigas (Thun.) and C. angulata (Lam.) are the most important cultured oyster species at a global level (Buestel et al., 2009; Hsiao et al., 2016), and hold major ecological (Grabowski et al., 2012) and socio-economic importance (FAO, 2015). However, these species present different ecophysiological traits (e.g. growth, filtration rate, energy metabolism) despite occupying the same ecological niche (Goulletquer et al., 1999; Soletchnik et al., 2002; Li et al., 2017), thus raising the question on how competitive advantages may define species resilience in a changing environment.

Proteomic approaches to evaluate environmental stress give powerful insights into the modes of action (MoA) involved in stress adaptation of marine organisms in response to external stimuli. Moreover, proteomics allows comparisons between closely related congeners and discriminate if different environmental stressors induce the same stress response (reviewed in Tomanek, 2015). Recent studies applied proteomics to assess closely related Mytilus congeners (Tomanek et al., 2011), and different breeding lines of Saccostrea glomerata (Thompson et al., 2016) in response to different environmental stressors (e.g. thermal, osmotic and hypercapnic stress). However, none of them focused on the combined effects of OA and As exposure.

Hence, the present study aimed to compare the response of two closely related oyster species, $C$. angulata and C. gigas, after laboratory exposures to As, OA (Low $\mathrm{pH}$ ), and the combined effects of both stressors (Low $\mathrm{pH}+\mathrm{As}$ ), bringing new insights on the ability of these species to respond to a changing environment. To achieve this objective, a proteomic approach was applied to compare protein expression profiles after 28 days of exposure.

\section{Materials and methods}

\subsection{Experimental setup}

Juvenile C. angulata and C. gigas specimens were obtained from aquaculture producers in the Sado estuary - Portugal (SW Europe) in April 2017. Similar-sized oysters were selected for laboratory exposures (2.6-3.8 cm height, $1.9-2.3 \mathrm{~cm}$ length). Oysters were acclimated to laboratory conditions for 6 weeks in separate $400 \mathrm{~L}$ tanks (one per species) in recirculated artificial seawater (Tropic Marine Sea Salt) set at $30 \pm 1$ salinity, $17^{\circ} \mathrm{C}$ (Hailea), UV filtration (TMC Vecton ${ }^{2}$ ), protein skimming (Deltec), and a total recirculation rate of $3000 \mathrm{~L} \mathrm{~h}^{-1}$ (Eheim). During the acclimation period seawater was partially renewed every 2 days (30\%) and completely renewed every week. After the first week of acclimation, oysters were fed live microalgae (Isochrysis galbana and Chaetoceros calcitrans) 5 days per week, at a daily ration of ca. $10^{9}$ cells $\mathrm{L}^{-1}$ day ${ }^{-1}$ (T-Iso equivalents cells).

After the acclimation period, oysters were transferred to $20 \mathrm{~L}$ aquaria (10 oysters per aquarium) in a triplicate design. Aquaria were filled with fresh seawater and used to simulate 4 separate conditions: control (CTL), As exposure (As), seawater acidification (Low pH) and the combination of seawater acidification and As exposure (Low $\mathrm{pH}+\mathrm{As})$.

For As exposure, a stock solution of sodium arsenate $\left(\mathrm{Na}_{3} \mathrm{AsO}_{4}\right)$ (CAS no. 10048-95-0) was directly spiked into aquaria to achieve a final concentration of $500 \mu \mathrm{g}$ As $\mathrm{L}^{-1}$. Arsenic exposure concentration was chosen considering: i) previous studies that showed sublethal effects of As to adult oysters (Zhang et al., 2015a; Moreira et al., 2016); median effect concentrations to oyster embryo-larval development (Martin et al., 1981; Mamindy-Pajany et al., 2013; Moreira et al., 2018); iii) data on As concentrations in the water column from suspended particulate matter (260 $\mathrm{mg} \mathrm{kg}^{-1}$, Ereira et al., 2015), and considering that OA increases the bioavailability of elements (Martín-Torre et al., 2017; Zeng et al., 2015).

Seawater acidification was achieved by $\mathrm{pH}$ manipulation using a $\mathrm{pH}$ stat system (Aquamedic) targeting a $0.4 \mathrm{pH}$ unit decrease from CTL conditions $(\mathrm{pH}=8.0)$ to $\mathrm{pH}$ 7.6. Seawater $\mathrm{pH}$ of acidified conditions was gradually lowered $0.1 \mathrm{pH}$ units per day until target $\mathrm{pH}$ level was achieved to prevent an abrupt change in seawater acidity. The chosen pH levels were based on: i) the average $\mathrm{pH}$ in the Sado Estuary sampling area (Amaral and Costa, 1999); ii) present global oceanic seawater $\mathrm{pH}$ and worst case scenario projections of $\mathrm{pH}$ decrease by year 2100 (Caldeira and Wickett, 2005; Raven et al., 2005); and $p \mathrm{CO}_{2}$ levels (ca. 600 and $1650 \mu \mathrm{atm}$ ) within those projected for estuarine systems under present and future acidification conditions (Tomanek et al., 2011; Melzner et al., 2012). To achieve this, independent $\mathrm{pH}$ probes were used to constantly monitor $\mathrm{pH}$ in every aquarium in all acidified conditions. Probes were linked to a central computer (Aquamedic) that enabled to automatically switch on or off a dedicated solenoid valve for each aquarium, enabling for $\mathrm{CO}_{2}$ gas to flow through glass diffusers and maintain targeted $\mathrm{pH}$ levels. Each $\mathrm{pH}$ electrode measurement was crosschecked with an independent probe (Hanna Instruments) at least every two days, and the $\mathrm{pH}$ stat system electrodes recalibrated if necessary.

Experimental exposures were performed during 28 days. Maintenance procedures included daily faecal debris removal (ca. $5 \%$ water change), feeding (I. galbana and C. calcitrans at $10^{9}$ T-Iso equivalent cells $\mathrm{L}^{-1}$ ) at least 5 days per week, As concentration replenishment, $\mathrm{pH}$ monitoring and total weekly water renewals. Prior to complete water renewals $\mathrm{pH}$, salinity and temperature were annotated (Hanna Instruments), and seawater samples collected from each 
Table 1

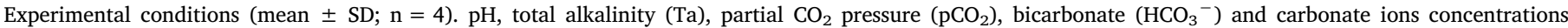

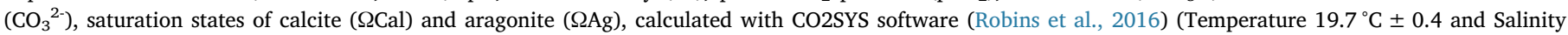
$31 \pm 1)$.

\begin{tabular}{|c|c|c|c|c|c|c|c|c|}
\hline Condition & & $\mathrm{pH}$ & $\mathrm{Ta}\left(\mu \mathrm{mol} \mathrm{kg}{ }^{-1}\right)$ & $\mathrm{pCO} 2(\mu \mathrm{atm})$ & $\mathrm{HCO}_{3}{ }^{-}\left(\mu \mathrm{mol} \mathrm{kg}{ }^{-1}\right)$ & $\mathrm{CO}_{3}^{-}\left(\mu \mathrm{mol} \mathrm{kg}{ }^{-1}\right)$ & $\Omega \mathrm{Ar}$ & $\Omega \mathrm{Ca}$ \\
\hline \multirow[t]{4}{*}{ C. angulata } & CTL & $8.01 \pm 0.03$ & $2046 \pm 54$ & $576 \pm 34$ & $1776 \pm 49$ & $110.2 \pm 5.2$ & $2.7 \pm 0.1$ & $1.8 \pm 0.09$ \\
\hline & As & $7.99 \pm 0.02$ & $2103 \pm 41$ & $599 \pm 28$ & $1830 \pm 37$ & $110.2 \pm 4.9$ & $2.7 \pm 0.1$ & $1.7 \pm 0.08$ \\
\hline & Low $\mathrm{pH}$ & $7.59 \pm 0.03$ & $2087 \pm 61$ & $1633 \pm 110$ & $1970 \pm 56$ & $46.4 \pm 3.6$ & $1.1 \pm 0.08$ & $0.7 \pm 0.05$ \\
\hline & Low $\mathrm{pH}+$ As & $7.59 \pm 0.02$ & $2129 \pm 44$ & $1734 \pm 99$ & $2015 \pm 42$ & $46.4 \pm 2.2$ & $1.1 \pm 0.05$ & $0.7 \pm 0.03$ \\
\hline \multirow[t]{4}{*}{ C. gigas } & CTL & $7.99 \pm 0.02$ & $2001 \pm 58$ & $586 \pm 21$ & $1743 \pm 49$ & $102.8 \pm 4.7$ & $2.5 \pm 0.1$ & $1.6 \pm 0.07$ \\
\hline & As & $7.98 \pm 0.04$ & $1996 \pm 59$ & $577 \pm 13$ & $1739 \pm 46$ & $102.8 \pm 5.9$ & $2.5 \pm 0.1$ & $1.6 \pm 0.09$ \\
\hline & Low $\mathrm{pH}$ & $7.57 \pm 0.01$ & $2040 \pm 64$ & $1732 \pm 84$ & $1933 \pm 63$ & $42.7 \pm 1.7$ & $1.1 \pm 0.04$ & $0.7 \pm 0.03$ \\
\hline & Low $\mathrm{pH}+\mathrm{As}$ & $7.58 \pm 0.02$ & $2027 \pm 62$ & $1654 \pm 62$ & $1920 \pm 55$ & $43.8 \pm 3.2$ & $1.1 \pm 0.08$ & $0.7 \pm 0.05$ \\
\hline
\end{tabular}

aquarium to determine total alkalinity (TA). TA was determined by potentiometric titration (Gran, 1952) for each aquarium every week and data obtained were plotted together with $\mathrm{pH}$, temperature and salinity measurements corresponding to the time of each sample collection in CO2SYS Calc software (Robbins et al., 2010) to further characterize seawater carbonate system parameters using $\mathrm{K} 1$ and $\mathrm{K} 2$ $\mathrm{CO}_{2}$ dissociation constants from Mehrbach et al. (1973) refit by Dickson and Millero (1987) and $\mathrm{KHSO}_{4}$ from Dickson (1990) (Table 1).

After 28 days exposure period, oysters were immediately frozen in liquid nitrogen, and stored at $-80^{\circ} \mathrm{C}$ for further analysis.

\subsection{Arsenic concentrations in oysters' soft tissue}

Total As concentration in oysters was quantified in whole soft tissue homogenates of 3 oysters from each experimental condition replicate, including in CTL following the protocol described in Freitas et al. (2012). Briefly, each specimen's soft tissue was homogenised using a mortar and pestle under liquid nitrogen. Known weight aliquots (ca. $0.3 \mathrm{~g}$ ) from each oyster were digested overnight in Teflon bombs with analytical grade $\mathrm{HNO}_{3}$ and $\mathrm{H}_{2} \mathrm{O}_{2}(30 \% \mathrm{w} / \mathrm{w})$ (Chem-Lab NV). The digested samples were analysed by inductively coupled plasma mass spectrometry (ICP-MS) and total As determined based on IV- $71 \mathrm{~A}$ standard (Inorganic Ventures). Calibration curve was verified with standard reference material (NIST SRM 1643) (calculated measure of trueness over $90 \%$ ). The recovery percentage of the digestion procedure was verified by parallel digestion of reference standard material TORT3 (Lobster Hepatopancreas, NRC Canada) and recovery percentages determined for As (103.7\%). Results were expressed in $\mu \mathrm{g} \mathrm{g^{-1 }}$ wet weight (w.w.).

\subsection{Protein extract preparation}

Oysters' whole soft tissue were used for protein extractions. For each species, the soft tissue of two oysters per condition replicate were pooled together, and 3 individual samples $(n=3)$ per experimental condition were analysed. Samples were weighed and homogenised (1:3 $\mathrm{w} / \mathrm{v}$ ) in $10 \mathrm{mM}$ HEPES buffer, $250 \mathrm{mM}$ sucrose, $1 \mathrm{mM}$ DTT, $1 \mathrm{mM}$ $\mathrm{Na}_{2}$ EDTA, $1 \mathrm{mM}$ PMSF, and protease inhibitor (Sigma Aldrich Tablets) with an Ultra-Turrax homogenizer on ice $\left(4^{\circ} \mathrm{C}\right)$. Homogenates were centrifuged at $15000 \mathrm{~g}\left(4^{\circ} \mathrm{C}\right)$ for $2 \mathrm{~h}$, and the cytosolic fraction (supernatant) collected, separated in aliquots and stored $\left(-80^{\circ} \mathrm{C}\right)$ or immediately used for protein concentration determination following the Bradford method using BSA as standard (Bradford, 1976).

Posteriorly, supernatant volume corresponding to $150 \mu \mathrm{g}$ protein from each sample was precipitated in 10\% TCA in acetone solution at $1: 9(\mathrm{v} / \mathrm{v})$ for $2 \mathrm{~h}$ at $-20^{\circ} \mathrm{C}$ and centrifuged at $10000 \mathrm{~g}$ for $30 \mathrm{~min}\left(4^{\circ} \mathrm{C}\right)$. After this procedure the pellet containing precipitated protein was washed with ice-cold acetone. Washing procedure was repeated three times, and the pellet left to dry for 3-5 min. The pellet containing dried protein extracts of each sample were reconstituted in $300 \mu \mathrm{L}$ lysis buffer (7 M urea, $2 \mathrm{M}$ thiourea, $4 \%(\mathrm{w} / \mathrm{v}$ ) CHAPS, $0.8 \%(\mathrm{w} / \mathrm{v})$ pharmalyte,
$65 \mathrm{Mm}$ DTT, protease inhibitor (Sigma Aldrich Tablets), and traces of bromophenol blue) for $30 \mathrm{~min}$, centrifuged at $14000 \mathrm{~g}$ for $10 \mathrm{~min}$. Samples were immediately used or stored at $-80^{\circ} \mathrm{C}$ for further analysis.

\subsection{Two-dimensional gel electrophoresis}

Two-dimensional gel electrophoresis was performed twice for each sample, in order to obtain 6 gel images representative of each condition. For the first-dimension protein separation by isoelectric focusing (IEF), the sample ( $150 \mu$ g protein in $300 \mu \mathrm{L}$ lysis buffer) was loaded into $24 \mathrm{~cm}$ ceramic immobilized pH gradient (IPG) holders (GE Healthcare). IPG strips (GE Healthcare Immobiline DryStrip pH 4-7, $18 \mathrm{~cm}$ ) were carefully introduced over each sample. The IPG ceramic holders were sealed with dedicated mineral oil (GE Healthcare DryStrip Cover Fluid) and lids, holding each sample and the IPG strip inside, were placed. IEF was performed on an Ettan IPGphor 3 System (GE Healthcare) set to develop the following programme: $6: 30 \mathrm{~h}$ at $0 \mathrm{~V}$ (rehydration); $6: 30 \mathrm{~h}$ at $50 \mathrm{~V}$ (fast); $1 \mathrm{~h}$ at $1000 \mathrm{~V}$ (linear); $1 \mathrm{~h}$ at $4000 \mathrm{~V}$ (fast); $1 \mathrm{~h}$ at $8000 \mathrm{~V}$ (linear); $1 \mathrm{~h} 8000 \mathrm{~V}$ (fast). After IEF, IPG strips containing separated proteins by their isoelectric point, were removed from the ceramic holders and stored at $-80^{\circ} \mathrm{C}$.

Before second-dimension protein separation, IPG strips were equilibrated by consecutive emersion in two SDS equilibration buffers ( $6 \mathrm{M}$ urea, 75 mM Tris-HCl pH 8.8; 29.3\% glycerol; 4\% SDS) for 15 min each: the first SDS equilibration buffer contained $1 \%(\mathrm{w} / \mathrm{v})$ DTT, $0.1 \mathrm{mM}$ EDTA, and a trace amount of bromophenol blue; the second SDS equilibration buffer contained $4 \%(\mathrm{w} / \mathrm{v})$ iodoacetamide, $0.1 \mathrm{mM}$ EDTA, and a trace amount of bromophenol blue. After equilibration, IPG strips were carefully placed on $10 \%(\mathrm{v} / \mathrm{v})$ polyacrylamide gels (made from 40\% Acrylamide/Bis Solution 37.5:1, Biorad) containing 0.1\% SDS (w/ $\mathrm{v}$ ), sealed using $0.5 \%$ agarose, and run under denaturing conditions in an Ettan Dalt 6 (GE Healthcare) refrigerated at $20^{\circ} \mathrm{C}$ following a twostep program: $15 \mathrm{~mA}$ and $5 \mathrm{w}$ per gel $(120 \mathrm{~V})$ for $30 \mathrm{~min}$; plus $60 \mathrm{~mA}$ and $17 \mathrm{~W}$ per gel $(500 \mathrm{~V})$ for ca. $5 \mathrm{~h}$ (until the front die reached the end of the gel). After second dimension separation, gels were fixed overnight in $40 \%(\mathrm{v} / \mathrm{v})$ ethanol and $10 \%(\mathrm{v} / \mathrm{v})$ acetic acid. Gels were silver stained following Blum et al. (1987). After staining, gels were scanned with a densitometer (Bio-Rad, GS-800).

A total of 6 gel images were obtained representative of each condition for each species (3 experimental replicates times 2 duplicates).

\subsection{Data analysis}

\subsubsection{Arsenic concentrations in oysters' soft tissue}

Statistical analysis was performed to verify the existence of significant differences concerning accumulated As concentrations among conditions using permutational analysis of variance (PERMANOVA) with PRIMER v6 software (Anderson et al., 2008). Briefly, hypotheses testing was performed on Euclidean distances similarity matrix constructed based on As concentration data of each sample. "Experimental 
condition" and "species" were defined as the fixed factors. One-way hierarchical designs considering 9999 permutations were followed to test the null hypothesis: $\mathrm{H}_{0}{ }^{\prime}=$ for each species no significant differences existed in total accumulated As among conditions; $\mathrm{H}_{0} "=$ for each condition no significant differences existed in total accumulated As between species. Significant differences $(p \leq 0.05)$ among conditions were represented with different letters, differences between species were represented with an asterisk.

\subsubsection{2-DE proteomic data analysis}

Gel image (2-DE map) analysis and statistics were performed using PDQuest software version 8.0.1 (Bio-Rad). Master gels representative of each condition were constructed based on 6 gels (3 experimental replicates times 2 duplicates). Protein spot intensity of each 2-DE map was normalized by total density of each gel image. Each protein spot assignment and matching between gels were verified using the software's matching and group consensus tools. Reproducibility of the 2-DE process was verified and accepted for mean coefficients of variation among gels representative of the same condition over $70 \%$. Analysis followed pairwise comparisons between all conditions by overlaying master gels' 2-DE maps. The analysis was performed separate for each species.

Protein expression was considered differentially altered between conditions whenever the intersection of quantitative (2-fold or higher) and statistically different ( $p \leq 0.05$, Student's $t$-test) spot intensity changes were observed. Differentially expressed protein spots were ranked by highest fold change in each condition, and the most important proteins (top 10 increased or decreased expression levels) for each condition were selected for excision and mass spectrometry analysis.

\subsection{Protein identification by mass spectrometry}

In-gel protein digestion was performed as outlined by Shevchenko et al. (2006). Before MS analysis, samples were resuspended in $10 \mu \mathrm{L}$ of formic acid $0.3 \%(\mathrm{v} / \mathrm{v})$ and $0.5 \mu \mathrm{L}$ of sample was hand-spotted onto a MALDI target plate (384-spot ground steel plate). Posteriorly, $1 \mu \mathrm{L}$ of a $7 \mathrm{mg} / \mathrm{mL}$ solution of $\alpha$-cyano-4-hydroxycinnamic acid matrix in $50 \%$ ( $\mathrm{vol} / \mathrm{vol}$ ) acetonitrile in aqueous trifluoroacetic acid $0.1 \%$ (vol/vol) was added and allowed to dry. Mass spectra were acquired on an Ultraflex II MALDI TOF mass spectrometer (Bruker) operated in positive ion mode using a reflectron $(\mathrm{m} / \mathrm{z}$ range of $600-3500)$. A total of 500 spectra were acquired for each sample at a laser frequency of $50 \mathrm{~Hz}$. External calibration was performed with $[\mathrm{M}+\mathrm{H}]^{+}$monoisotopic peaks of bradykinin 1-7 ( $m / z$ 757.3992), angiotensin II ( $m / z$ 1046.5418), angiotensin I $(m / z 1296.6848)$ substance P $(m / z 1758.9326)$, ACTH clip $1-17(m / z$ 2093.0862), ACTH18-39 ( $\mathrm{m} / \mathrm{z} 2465.1983)$ and somatostatin $28(\mathrm{~m} / \mathrm{z}$ 3147.4710). Peptide mass fingerprints (PMF) were searched via MASCOT search engine set for the following parameters: (i) NCBInr Crassostrea (138572 sequences; 81064928 residues); (ii) molecular weight of protein: all; (iii) two missed cleavage; (iv) fixed modifications: carbamidomethylation $(\mathrm{C})$; (v) variable modifications: oxidation of methionine and (vi) peptide tolerance up to $100 \mathrm{ppm}$. The significance threshold was set to a minimum of $95 \%(p \leq 0.05)$. Protein matching was considered successful when protein identification score was located out of the random region (Mascot score $\geq 64$ ).

\section{Results and discussion}

\subsection{Arsenic accumulation in oyster tissues}

Overall, the average concentration of As in oysters ranged from ca 1.0 to $5.4 \mu \mathrm{g} \mathrm{g}^{-1}$ w.w. in both species (Fig. 1) (equivalent to ca. 5 and $27 \mu \mathrm{g} \mathrm{g}^{-1}$ dry weight (d.w.) (Zhang et al., 2013). Residual As concentrations (ca. $1 \mu \mathrm{g} \mathrm{g}^{-1}$ w.w.) were observed in both oyster species (CTL), evidencing As contamination levels in the estuary where oysters

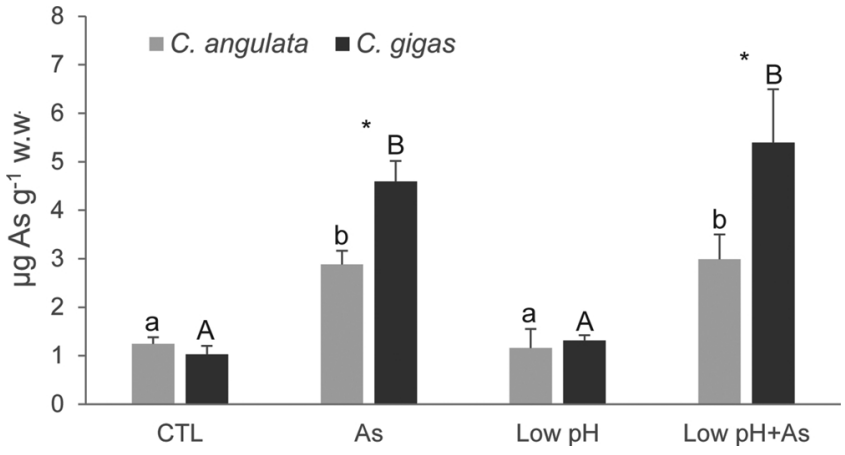

Fig. 1. Arsenic concentrations (mean $+\mathrm{SD} ; \mathrm{n}=9$ ) in juvenile $C$. angulata and C. gigas whole soft tissues unexposed (CTL) and exposed for 28 days to As, Low $\mathrm{pH}$ and Low $\mathrm{pH}+$ As. Significant differences in As concentrations between conditions are represented with different letters: lower-case letters for $C$. angulata and upper-case letters for $C$. gigas. Significant differences between species in each condition are represented with *.

were collected (Costa et al., 2009). In the present study, the highest As concentrations $\left(5.4 \mu \mathrm{g} \mathrm{g}^{-1}\right.$ w.w. $=$ ca. $27 \mu \mathrm{g} \mathrm{g}^{-1}$ d.w.) accumulated in oyster tissues after exposures were equivalent to reported values in oysters collected in other estuarine systems e.g. up to $26.7 \mu \mathrm{g} \mathrm{g}^{-1}$ d.w. in C. gigas in France (Kohlmeyer et al., 2002) and $25.4 \mu \mathrm{g} \mathrm{g}^{-1}$ d.w. in $C$. virginica from the U.S.A. (Valette-Silver et al., 1999).

No significant differences were observed concerning As concentration between unexposed (CTL) and exposed oysters at Low $\mathrm{pH}$ for either species (Fig. 1), while As concentrations were significantly higher in both As exposures (As; Low $\mathrm{pH}+\mathrm{As}$ ) than in CTL. No significant differences were observed in accumulated As concentrations between oysters exposed to As and those exposed to Low $\mathrm{pH}+$ As in either species (Fig. 1). These results show that seawater acidification did not influence oysters' uptake/excretion dynamics of As. A previous study conducted by Moreira et al. (2016) also demonstrated that As accumulation patterns of fully grown $C$. gigas and $C$. angulata year recruits was not influenced by seawater acidification.

Between-species comparison of As concentrations in oyster tissues within each experimental condition showed that $C$. gigas accumulated significantly higher amounts of As than C. angulata (in both As and Low $\mathrm{pH}+$ As conditions). Factors such as higher filtration/metabolic rates in C. gigas (Heral et al., 1986; Goulletquer et al., 1999) and likely higher metal tolerance in C. angulata (Cross et al., 2014) could explain different accumulation capacities observed between species, highlighting previously described ecophysiological differences between these closely related congeners (His, 1972; Heral et al., 1986; Soletchnik et al., 2002; Moreira et al., 2016 among others).

\subsection{Protein changes in Crassostrea angulata and Crassostrea gigas}

Proteomic analysis of $C$. angulata showed differentially expressed protein profiles between all tested conditions (Fig. 2). Protein identification through MS allowed to identify several proteins with significantly altered expression levels among conditions, which play biological roles related to metabolism (ATP synthase subunit $\beta$ ), cytoskeletal structure (Actin, Coronin 1-B; Severin; Gelsolin) cellular stress response (Retinal dehydrogenase, Lactoylglutathione lyase and Alpha crystallin b chain), cell signalling (progesterone-inducedblocking factor 1; piRNA biogenesis protein) proteolysis (aminopeptidase W07G4.4), cell differentiation/apoptosis (MYCBP-associated protein), cell to cell adherence related proteins (Ependymin, Tight junction protein ZO-1), transport (V-type proton ATPase subunit B), as well as two uncharacterized proteins (KIAA1109-like isoform X5; LOC105343084 isoform X1) (Table 2 and Fig. 2).

Proteomic analysis of $C$. gigas also showed differentially expressed protein profiles between all tested conditions (Fig. 2). MS analysis 

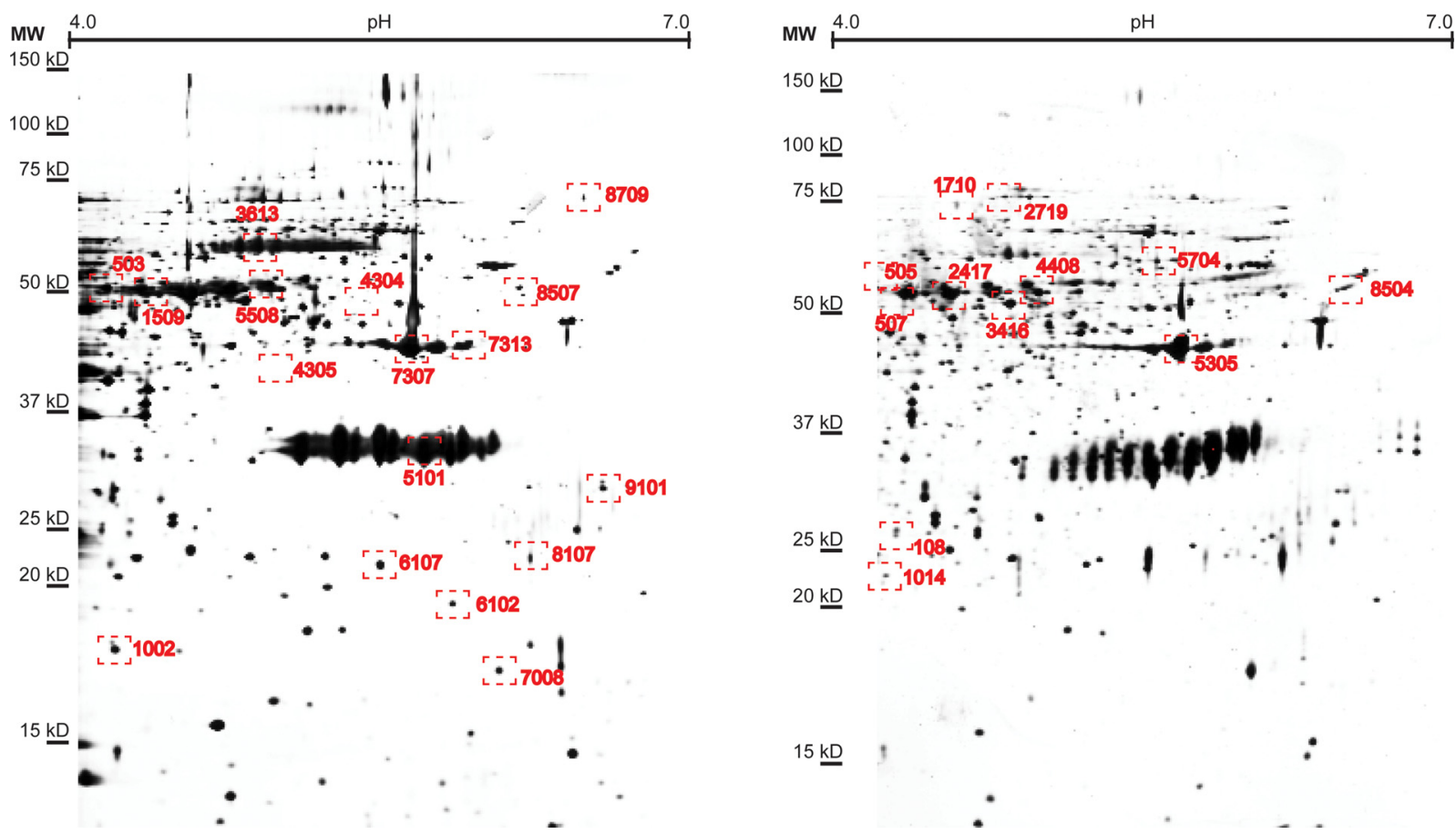

Fig. 2. Protein expression profile of juvenile $C$. angulata (left) and C. gigas (right) whole soft tissue by 2-DE. Differentially expressed proteins identified by MALDI TOF MS are highlighted in each representative gel image.

allowed to identify significantly altered proteins with biological functions related to metabolism (Enolase; Aconitate hydratase), cytoskeletal structure (Actin; Atlastine), extracellular structure (Neprilysin) and cellular stress response (Heme-binding protein 2; Arginine-tRNA-protein transferase 1; Alpha crystallin a chain; Atypical serine-protein kinase ATM; Aldehyde dehydrogenase; and Retinal dehydrogenase) (Table 2 and Fig. 2). One uncharacterized protein LOC105317411 (annotated in the $C$. gigas genome) was also identified, but its molecular and biological roles remain unknown.

Exposure of oysters to different scenarios of environmental stress such as As exposure (As), seawater acidification (Low pH), and simultaneous exposure to seawater acidification and As (Low $\mathrm{pH}+\mathrm{As}$ ) allowed to observe different protein expression profiles compared to control (CTL), but also among all stress conditions providing a deeper insight into the mechanisms involved in the responses of both species to different environmental stimuli.

\subsection{Crassostrea angulata}

\subsubsection{Protein changes under As exposure}

C. angulata exposed to As presented higher expression levels of cytoskeleton-related proteins compared to levels observed in CTL, namely Actin (Actin), Severin (Severin) and Gelsolin-like protein 2 (Gelsolin) (Table 2). Alterations in the expression levels of cytoskeletal proteins is a common response observed in marine organisms exposed to environmental stress (Tomanek, 2014). Altered levels of Actin have also been reported in other oyster species ( $S$. cucculata and $S$. glomerata) exposed to different types of contaminants (Muralidharan et al., 2012; Thompson et al., 2012; Khondee et al., 2016; Melwani et al., 2016), and could be indicative of cytoskeleton rearrangement to prevent oxidative damage (Dailianis et al., 2009).

Additionally, Severin and Gelsolin (both assigned to the Gelsolin superfamily) that play regulatory roles on Actin filament assembly and disassembly processes, are key proteins in cytoskeleton structure maintenance and remodelling (Silacci et al., 2004). The expression levels of these proteins were increased in As-exposed $C$. angulata relative to CTL (and to Low pH), and further corroborate the role of Actin dynamics in $C$. angulata stress response to As. Other studies have described altered levels of Severin and Gelsolin-like proteins in bivalves experiencing environmental stress. For instance, increased expression of Severin has been described in C. gigas under thermal and hypercapnic stress (Dineshram et al., 2015; Harney et al., 2016), and in S. glomerata exposed to highly polluted sites (Melwani et al., 2016). Likewise, altered abundance of Gelsolin-like proteins was described in S. cucculata exposed to TBT (Khondee et al., 2016), and Pecten maximus under hypoxia (Artigaud et al., 2015). In addition the importance of cytoskeletal proteins on Actin dynamics regulation, several other biological functions have been linked to Gelsolin superfamily proteins, which include modulation of cell motility, cortical shape changes, apoptosis and phagocytosis (Silacci et al., 2004; Li et al., 2009). Considering these studies, and the present findings showing increased expression of Actin, Severin and Gelsolin in C. angulata exposed to As, results suggest eminent cytoskeleton remodelling and could also be indicative of a proapoptotic cellular status in $C$. angulata exposed to As.

Lactoylglutathione lyase ( $\mathrm{Lgl}$ ) levels were significantly lower in $C$. angulata exposed to As compared to the remaining conditions including CTL (Table 2). Other studies have shown a negative correlation between $\mathrm{Lgl}$ and pollutant exposure, including in Macoma balthica exposed to As (Regoli et al., 1998), and in S. glomerata exposed to highimpacted sites (PAHs, PCBs, TBT, Pb and Zn) (Melwani et al., 2016). This enzyme is important in the glyoxalase system by participating in detoxification reactions of reactive $\alpha$-ketoaldehydes (glycolytic byproducts) using glutathione as cofactor (Regoli and Giuliani, 2014). Provided that $\mathrm{Lgl}$ regulation depends on cellular redox status (Birkenmeier et al., 2010), it is possible that the decrease of Lgl abundance indicates cellular redox imbalance induced by As exposure.

Decreased expression of Progesterone-induced blocking factor (Pibf), was observed in C. angulata exposed to As compared to CTL (also compared to Low $\mathrm{pH}+\mathrm{As}$ ) (Table 1). In mammals, Pibf is involved in immunomodulation, cytotoxic control, cell cycle regulation, cytokine 
Table 2

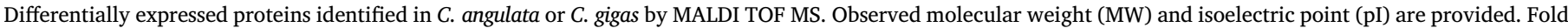

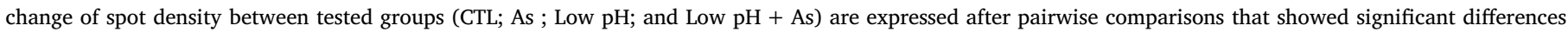
$(\mathrm{p} \leq 0.05)$.

\begin{tabular}{|c|c|c|c|c|c|c|}
\hline \multicolumn{7}{|c|}{ Crassostrea angulata } \\
\hline Spot no. & GenBank ass. no. & Protein name & Mascot score & $\begin{array}{l}\text { MW(kDa)/ } \\
\text { pI }\end{array}$ & Putative biological function(s) & Fold change \\
\hline 503 & XP_011429993.1 & Putative aminopeptidase W07G4.4 & 64 & $51.8 / 4.3$ & Proteolysis & $\begin{array}{l}3.3 \uparrow \text { in Low } \mathrm{pH}+\text { As vs. Low } \\
\mathrm{pH} \\
7.1 \uparrow \text { in Low } \mathrm{pH}+\text { As vs. As }\end{array}$ \\
\hline 1002 & XP_011447841.1 & MYCBP-associated protein-like isoform X5 & 64 & $18.5 / 4.4$ & Cell differentiation and apoptosi & $9.1 \uparrow$ Low $\mathrm{pH}+$ As vs. As \\
\hline 1509 & XP_011436817.1 & Retinal dehydrogenase 1 & 108 & $59.5 / 4.5$ & Regeneration & $2.3 \uparrow$ in Low pH vs. CTL \\
\hline 3613 & XP_011429476.1 & Coronin-1B isoform $\mathrm{X} 5$ & 118 & $64.0 / 4.9$ & Cytoskeleton & $2.6 \uparrow$ in Low $\mathrm{pH}+$ As vs. CTL \\
\hline 4304 & EKC22157.1 & Severin & 108 & $55.1 / 5.2$ & Cytoskeleton & $\begin{array}{l}4.3 \uparrow \text { in As vs. CTL } \\
4.8 \uparrow \text { in As vs. Low pH }\end{array}$ \\
\hline 4305 & ЕКС30581.1 & Progesterone-induced-blocking factor 1 (Pibf) & 100 & $38.6 / 5.0$ & Immunomodulation & $\begin{array}{l}5.0 \uparrow \text { CTL vs. As } \\
10.0 \uparrow \text { in Low } \mathrm{pH}+\text { As vs. As }\end{array}$ \\
\hline 5101 & XP_022328428.1 & $\begin{array}{l}\text { Uncharacterized protein KIAA1109-like isoform } \\
\text { X5 }\end{array}$ & 64 & $34.0 / 5.5$ & Lipid metabolism & $\begin{array}{l}2.8 \uparrow \text { in As vs Low } \mathrm{pH} \\
4.2 \uparrow \text { in As vs. Low } \mathrm{pH}+\text { As }\end{array}$ \\
\hline 5508 & ЕКC36437.1 & V-type proton ATPase subunit B & 73 & $53.3 / 5.1$ & Transport & $\begin{array}{l}3.3 \uparrow \text { in Low pH vs. Low } \\
\mathrm{pH}+\text { As }\end{array}$ \\
\hline 6102 & EKC27629.1 & Alpha-crystallin B chain & 111 & $17.3 / 5.6$ & Molecular chaperone & $\begin{array}{l}2.0 \downarrow \text { in As vs Low pH }+ \text { As } \\
3.0 \downarrow \text { in Low pH }+ \text { As vs. CTL } \\
4.3 \downarrow \text { in As vs Low pH } \\
6.3 \downarrow \text { in As vs. CTL }\end{array}$ \\
\hline 6107 & XP_011413901.1 & Ependymin-related protein 1 & 114 & $22.0 / 5.3$ & Cell-matrix adhesion & $\begin{array}{l}4.4 \uparrow \text { in Low pH vs. Low } \\
\mathrm{pH}+\mathrm{As}\end{array}$ \\
\hline 7008 & XP_011422530.1 & Lactoylglutathione lyase & 118 & $17.8 / 5.7$ & Antioxidant defense & $\begin{array}{l}5.9 \uparrow \text { in Low pH }+ \text { As vs. As } \\
5.6 \uparrow \text { in CTL vs. As } \\
5.9 \uparrow \text { in Low pH vs. As }\end{array}$ \\
\hline 7303 & XP_011427051.1 & Gelsolin-like protein 2 & 80 & $54.6 / 5.9$ & Cytoskeleton & $\begin{array}{l}2.6 \uparrow \text { in As vs. Low pH } \\
4.1 \uparrow \text { in As vs. CTL }\end{array}$ \\
\hline 7307 & NP_001295788.1 & Actin & 78 & $47.6 / 5.6$ & Cytoskeleton & $\begin{array}{l}4.7 \uparrow \text { in Low pH }+ \text { As vs. CTL } \\
5.9 \uparrow \text { in As vs. CTL }\end{array}$ \\
\hline 8107 & XP_022321285.1 & piRNA biogenesis protein EXD1-like & 64 & $26.4 / 5.9$ & Cell signaling & $6.7 \downarrow$ in Low $\mathrm{pH}+$ As vs. CTL \\
\hline 8507 & ЕКС39411.1 & ATP synthase subunit beta. mitochondrial & 64 & $65.5 / 5.8$ & Oxidative phosphorylation & $\begin{array}{l}2.8 \downarrow \text { in Low pH }+ \text { As vs. CTL } \\
5.2 \downarrow \text { in Low pH vs. CTL }\end{array}$ \\
\hline 8709 & EKC34842.1 & Tight junction protein ZO-1 & 88 & $91.1 / 6.0$ & Cell-Cell adherence & $\begin{array}{l}6.7 \uparrow \text { in CTL vs As } \\
7.1 \uparrow \text { in Low pH vs. As } \\
10.0 \uparrow \text { in Low pH }+ \text { As vs. As }\end{array}$ \\
\hline 9101 & XP_011448567.1 & $\begin{array}{l}\text { Uncharacterized protein LOC105343084 } \\
\text { isoform X1 }\end{array}$ & 83 & $28.0 / 6.0$ & Unknown & $\begin{array}{l}2.5 \uparrow \text { in Low pH vs. Low } \\
\mathrm{pH}+\mathrm{As}\end{array}$ \\
\hline \multicolumn{7}{|c|}{ Crassostrea gigas } \\
\hline Spot no. & GenBank ass. no. & Protein name & Mascot score & $\mathrm{MW}(\mathrm{kDa}) / \mathrm{pi}$ & Putative biological function(s) & Fold change \\
\hline 108 & ЕКС31868.1 & Arginyl-tRNA-protein transferase 1 & 65 & $28.1 / 4.6$ & Stress signalling/apoptosis & $4.5 \downarrow$ in As vs. CTL \\
\hline 505 & CGI_10013191 & Atlastin-2-like isoform X4 & 64 & $60.9 / 4.4$ & ER Dynamics & $3.1 \uparrow$ in Low pH vs. CTL \\
\hline 507 & XP_022316405.1 & Neprilysin-2-like & 64 & $54.6 / 4.5$ & Extracelular structure & $2.4 \uparrow$ Low pH vs. CTL \\
\hline 1014 & XP_011448780.1 & Alpha-crystallin A chain & 90 & $23.5 / 4.5$ & Stress protein & $7.1 \downarrow$ in As vs. Low ph \\
\hline 1710 & XP_011445349.1 & Heme-binding protein 2 & 60 & $82.1 / 4.6$ & $\begin{array}{l}\text { Redox balance } \\
\text { Imune response }\end{array}$ & $2.6 \uparrow$ in As vs. CTL \\
\hline 2417 & XP_011436817.1 & Retinal dehydrogenase & 129 & $59.5 / 4.5$ & Stress response & $2.2 \uparrow$ in Low $\mathrm{pH}$ vs Low $\mathrm{pH}+$ As \\
\hline 2719 & XP_011411873.1 & Aconitate hydratase isoform X2. cytoplasmic & 90 & $91.8 / 4.7$ & Metabolism & $2.7 \uparrow$ in As vs Low $\mathrm{pH}$ \\
\hline 3416 & XP_011436228.1 & Enolase & 87 & $55.6 / 4.9$ & Glycolitic process & $2.8 \uparrow$ in Low $\mathrm{pH}$ vs. Low $\mathrm{pH}+$ As \\
\hline 4408 & XP_011450475.1 & Aldehyde dehydrogenase. mitochondrial & 94 & $59.5 / 4.8$ & Antioxidant & $2.9 \uparrow$ in Low $\mathrm{pH}+$ As vs Low $\mathrm{pH}$ \\
\hline 5305 & EKC30048.1 & Actin & 119 & $45.7 / 5.4$ & Cytoskeleton & $\begin{array}{l}3.8 \uparrow \text { in Low } \mathrm{pH} \text { vs. Low } \mathrm{pH}+\text { As } \\
4.0 \uparrow \text { in Low } \mathrm{pH} \text { vs. As } \\
4.1 \uparrow \text { in Low } \mathrm{pH} \text { vs. CTL }\end{array}$ \\
\hline 5704 & XP_019919028.1 & Serine-protein kinase ATM & 65 & $66.8 / 5.4$ & $\begin{array}{l}\text { Cell cycle } \\
\text { Stress response }\end{array}$ & $2.2 \uparrow$ in Low pH + As vs. CTL \\
\hline 8504 & CGI_10008427 & Uncharacterized LOC105317411 & 64 & $61.5 / 6.0$ & Unknown & $\begin{array}{l}2.9 \downarrow \text { in Low pH vs. CTL } \\
2.3 \downarrow \text { Low } \mathrm{pH} \text { vs. Low } \mathrm{pH}+\text { As }\end{array}$ \\
\hline
\end{tabular}

balance and cell invasion (Laskarin et al., 2002; Szekeres-Bartho et al., 2005; Balassa et al., 2018). Moreover, Pibf is involved in cell signalling processes by interaction with the interleukin-4 binding system. Although the current knowledge on Interleukin signalling pathways in marine bivalves is still in its infancy (Malagoli, 2010; Li et al., 2014), interleukins are known effectors that modulate inflammatory response of organisms to pathogens, tissue injury and irritants (Liu et al., 2015). Considering this, the present data suggest that decreased expression levels of Pibf observed in C. angulata exposed to As were likely related to inflammatory response regulation and modulation of the interleukin4 binding system. Because Pibf deficiency generally enables natural killer cell activity (Szekeres-Bartho et al., 2005), our data showing lower Pibf could also indicate a pro-apoptotic status of $C$. angulata exposed to As.

Expression levels of Alpha crystallin b chain ( $\alpha$-crystallin b), a member of the small heat shock protein family (sHsp) family were lower in C. angulata exposed to As compared to all other tested conditions (Table 2). Heat shock proteins are molecular chaperones 
ubiquitous to all clades of life, which maintain correct folding profiles of native proteins, and are generally conceived to be induced in response to a variety of stress stimuli (Gupta et al., 2010). However, the Hsp response in bivalves can be highly dynamic, depending on tissue, time of exposure and type of Hsp (reviewed by Fabbri et al., 2008). For instance, Zhang et al. (2015b) observed increased levels of several sHsps in C. gigas exposed to thermal stress, whilst no alteration in the same proteins were observed in oysters exposed to hypoosmotic stress or aerial exposure. Park et al. (2016) also observed differential expression profiles of the gene expression of several Hsp families in response to different biofouling agents. Therefore, our results showing decreased expression of $\alpha$-crystallin b could result from concerted regulation of Hsps in response to As exposure. Moreover, $\alpha$-crystallin $b$ depletion could be indicative a pro-apoptotic status according to Acunzo et al. (2012), and therefore could indicate a deleterious cellular status in C. angulata exposed to As, also in line with results from Pibf, Severin and Gelsolin previously described.

C. angulata exposed to As showed significantly lower Tight junction ZO-1 protein (ZO-1) levels than in all other conditions (Table 2). ZO-1 are scaffolding proteins integral in the link between the tight junction and the actin cytoskeleton, modulating cell to cell adherence processes. Different elements have been shown to cause tight junction restructuring and deficiency, for instance in mouse respiratory cells exposed to As (Sherwood et al., 2013) and in Tegillarca granosa clams exposed to Cd (Bao et al., 2016). Therefore, the present data suggest that As caused impairment of cell to cell adherence proteins in C. angulata.

Adding to differences observed between As exposure and CTL, data showed increased expression of Uncharacterized protein KIAA1109-like (spot no. 5001, Table 2) in C. angulata exposed to As compared to both acidification conditions (Low $\mathrm{pH}$ and Low $\mathrm{pH}+\mathrm{As}$ ). This protein is assigned to the Fragile site-associated protein (Fsa) domain. Abundance of this protein was higher in oysters exposed to As compared to Low $\mathrm{pH}$ (and to Low $\mathrm{pH}+\mathrm{As}$ ). Fsa's C-terminus shares high similarity with lpd3 gene (Kuo et al., 2006) that is related to lipid storage in nematode Caenorhabditis elegans (McKay et al., 2003). The present results on increased KIAA1109-like protein in C. angulata exposed to As could be related to alterations in lipid metabolism due to As as observed in other organisms (Carlson and Van Beneden, 2014; Wang et al., 2015).

\subsubsection{Protein changes under Low $p H$}

C. angulata exposed to Low pH presented lower abundance of ATP synthase subunit betta (ATP $\beta$ ) in comparison to CTL (Table 2). Other studies have also described ATP synthase subunit depression in marine invertebrates exposed to acidification, namely in coral (Moya et al., 2012), polychaete (Wäge et al., 2016) and bivalve (Hüning et al., 2013) species including C. gigas (Harney et al., 2016). ATP synthase is a protein complex situated in the inner mitochondrial membrane and is an important player in ATP synthesis in all living organisms. The decrease of ATP synthase subunit's expression has been discussed as a means of oxidative metabolism suppression (Moya et al., 2012). Metabolic arrest is characteristic of organisms incurring extreme stress (Guppy and Withers, 1999), likely resulting from decreased aerobic scope for ATP synthesis (Sokolova et al., 2012) and a possible indication of a shift to anaerobic metabolism (Hüning et al., 2013). Hence, the decrease of ATP synthase $\beta$ expression levels observed in C. angulata in Low $\mathrm{pH}$ condition most likely indicate metabolic depression in response to acidification in this species.

Another protein, retinal dehydrogenase (Rdh), increased in C. angulata compared to CTL (Table 2). Thompson et al. (2015) also observed increased Rdh in Saccostrea glomerata exposed to high $p \mathrm{CO}_{2}$. Rdhs catalyse the irreversible oxidation of retinal to retinoic acid (RA) (Gutierrez-Mazariegos et al., 2014). Thus, increased expression of Rdh potentially increases RA concentration in oyster tissues. The physiological effects of such alterations in invertebrates remain to be clarified although RA seems to be involved in several processes from organ formation to differentiation and regeneration (Albalat, 2009; GutierrezMazariegos et al., 2014). The present data, showing increased expression of Rdh suggests a protection mechanism towards acidification.

\subsubsection{Protein changes under Low $\mathrm{pH}+$ As}

Coronin is an actin filament binding protein that participates in Actin dynamics, including filament disassembly, bundling, crosslinking and several other actin network reorganization processes (Rybakin and Clemen, 2005; Lin et al., 2010; Srivastava et al., 2015). In the present study, increased expression of Coronin suggests alterations of Actin dynamics related to cytoskeleton restructuring in $C$. angulata exposed to Low $\mathrm{pH}+$ As. Concomitantly, results also showed increased expression of Actin in the same condition, supporting the effective role of increased Coronin observed. Accordingly, other studies (Thompson et al., 2015, 2016) also observed simultaneous increase of both Coronin and Actin in S. glomerata exposed to acidification.

Alpha crystallin b ( $\alpha$-crystallin b) expression levels were lower in Low $\mathrm{pH}+$ As compared to CTL, similar to results observed in oysters exposed to As. However, the decrease of protein expression levels was 2-fold lower than that observed by As single exposure (Table 2). These findings could be related to the fact that Hsp expression can depend on oysters' energetic fitness. C. gigas also presented lower levels of Hsp70 and Hsp69 in close relation to depleted energetic reserves (Li et al., 2007).

Decreased expression levels of ATP synthase $\beta$ observed in Low $\mathrm{pH}+$ As in relation to CTL (Table 2) evidenced energetic efficiency modulation. In line with results observed for Low $\mathrm{pH}$ single exposure previously discussed, lower ATP synthase $\beta$ abundance was likely related to suppression of oxidative metabolism in $C$. angulata exposed to Low $\mathrm{pH}$. However, the decrease of ATP $\beta$ was lower ( 2.8 fold) in Low $\mathrm{pH}+$ As than in Low $\mathrm{pH}$ single exposure (5.2 fold) (Table 2), an indication that metabolic adjustment was differentially modulated under the combination of both stressors (Low $\mathrm{pH}+\mathrm{As}$ ).

piRNA biogenesis protein (piRNA) expression levels were lower (6.7-fold) in Low $\mathrm{pH}+$ As comparing to CTL (Table 2). piRNAs are involved in genome integrity maintenance via transposon regulation (Mani and Juliano, 2013; Iwasaki et al., 2015). Transposable elements (TEs) are mobile DNA sequences that can move within the genome, and are silenced by piRNAs (Luo and Lu, 2017). Researchers have recently proposed that stress-induced TE mobility via piRNA suppression allows for genome reconfiguration in response to extreme environmental stress (Ryan et al., 2016), enabling for heritable phenotypic variation (Piacentini et al., 2014). Considering this theory, and the fact that TEs are abundant in the oyster genome (Cross et al., 2014), the present data showing decreased expression levels of piRNA biogenesis protein in $C$. angulata exposed to Low $\mathrm{pH}+$ As could imply genome reconfiguration in response to multiple stressors, a novel observation concerning adaptive evolution mechanisms in oysters.

Apart from proteomic differences observed between Low $\mathrm{pH}+\mathrm{As}$ and CTL, our results also revealed differences in protein abundance profiles between stress conditions (Table 2). For instance, abundance of Aminopeptidase W07G4.4 (Aminopeptidase) and MYCBP-associated protein (Mycbp) increased in Low $\mathrm{pH}+$ As compared to Low $\mathrm{pH}$ and/or As. On the other hand, C. angulata presented lower abundance of V-type proton ATPase subunit B (V-ATPase b), Ependymin-related protein 1 (Epend-1) and one uncharacterized protein (spot number 9101) in Low $\mathrm{pH}+$ As compared to levels in Low pH single exposure (Table 2).

Increased levels of Aminopeptidase have also been described in $S$. glomerata oysters exposed to seawater acidification (Thompson et al., 2016), although expression levels of the same Aminopeptidase were decreased in oysters from highly contaminated sites (Melwani et al., 2016). Aminopeptidase molecular function suggests a primary role in protein catabolism (Brooks and Isaac, 2004) and therefore, increased level of Aminopeptidase in C. angulata exposed to Low $\mathrm{pH}+\mathrm{As}$ indicates higher protein turnover necessary to endure oxidative stress (Sokolova et al., 2012). 
Expression levels of MYCBP-associated protein (Mycbp) were higher in Low $\mathrm{pH}+$ As compared to As single exposure. Mycbp is related to cell growth, proliferation and apoptosis by modulating Myc gene activity (Young et al., 2011). Additionally, recent studies showed that Mycbp is a positive modulator of the Hedgehog signalling pathway (Lin et al., 2014), which is conserved among metazoans (Ingham et al., 2011). The roles of Hedgehog post-natal signalling have been recently reviewed by Smelkinson (2017), and include tissue homeostasis maintenance and immunity, which can be activated by pathogenic agents, tissue injury and damaging agents. Considering this, the present results showing increased levels of Mycbp in C. angulata exposed to Low $\mathrm{pH}+$ As could be linked to Hedgehog signalling activation, as a response mechanism resulting from external stress stimuli for homeostatic maintenance. The fact that significant differences between Low $\mathrm{pH}+\mathrm{As}$ and As conditions were observed for Mycbp, agrees with the present overall analysis showing that oysters exposed to As alone were experiencing a different kind of external aggression from that in Low $\mathrm{pH}+\mathrm{As}$.

Results showing increased levels of V-ATPase b protein in Low $\mathrm{pH}$ compared to Low $\mathrm{pH}+$ As are in line with previous studies that described V-ATPase b increase in other oyster species (C. gigas and $S$. glomerata) exposed to OA (Dineshram et al., 2012; Thompson et al., 2015). V-ATPases are ATP consuming ion channels that play roles in acid-base regulation $\left(\mathrm{HCO}_{3}{ }^{-}\right)$, calcification, carbon concentrating processes, as well as excessive proton excretion in marine invertebrates exposed to OA (Parker et al., 2013; Ivanina and Sokolova, 2015; Tresguerres, 2016). Interestingly, oysters exposed to Low pH + As did not induce increased expression of V-ATPase $b$ (Table 1), evidencing that As influenced oysters' response to acidification. This could be related to the energetic costs associated to V-ATPase,s activity (Tresguerres, 2016) and the possible preferential energy allocation towards As detoxification processes in Low $\mathrm{pH}+$ As condition. These results highlight different modes of action of $C$. angulata towards multiple stressors.

Ependymin related-protein 1 (Epend) expression levels were also increased in Low pH compared to Low $\mathrm{pH}+$ As (Table 2). Ependymin's physiological role is related to cell adhesion processes through cellmatrix contact formation. Generally, increased expression of these proteins reflects tissue remodelling in response to environmental stimuli as reported in Littorina saxatilis (Muraeva et al., 2016) and C. gigas (Zhao et al., 2012) under osmotic stress. Zhang et al. (2015b), observed a versatile behaviour of ependymin proteins in C. gigas exposed to different abiotic factors. These authors described increased expression of Ependymin in oysters exposed to thermal and osmotic stress, while the expression levels of the same proteins were lower under aerial exposure. The present results suggest that Low $\mathrm{pH}$ induced higher Epend to modulate cell adhesion, while in the presence of As (Low pH + As) C. angulata presented lower capacity to promote Epend biosynthesis with possible impacts on tissue structure modulation capacity.

Other proteins presenting altered abundance levels in single exposures (Low $\mathrm{pH}$ or As) did not present the same alteration in oysters exposed to the combination of both stressors (e.g. Rdh, Severin, Gelsolin, Pibf, ZO-1). No alteration of Rdh levels was observed in $C$. angulata exposed to Low $\mathrm{pH}+$ As, contrasting with increased expression of Rdh in Low pH single exposure, could be related to inhibition of this enzyme by metals (Luo et al., 2014; Meng et al., 2015; Bao et al., 2016). These data show that the combined effects of Low $\mathrm{pH}$ and As induce a different response from that of the isolated exposure to Low $\mathrm{pH}$ regarding Rdh, with likely implications at the physiological level.

Both Severin and Gelsolin, that increased in As single exposure, did not show alterations under Low $\mathrm{pH}+$ As, evidencing that multiple stressors induced a differentiated response capacity at the cytoskeletal level. Moreover, C. angulata exposed to Low $\mathrm{pH}+$ As presented the highest fold change of ZO-1 (10-fold lower, Table 1) and Pibf abundance (10-fold higher) compared to single As exposure, indicating a stronger modulation of cell to cell adherence capacity (ZO-1), and higher immunomodulation response (Pibf) in C. angulata exposed to multiple stressors.

\subsection{Crassostrea gigas}

\subsubsection{Protein changes under As exposure}

Differentially expressed proteins identified in C. gigas exposed to As in comparison to CTL were Heme-binding protein 2 (Heme-bp) and Arginyl-tRNA-protein transferase 1 (Ate-1) (Table 2).

Expression levels of Heme-binding protein 2 (Heme-bp), assigned to the SOUL heme-binding superfamily, were increased in $C$. gigas exposed to As. Other studies have described upregulated heme binding genes in marine invertebrates under environmental stress, including $C$. gigas infected by Ostreid herpesvirus-1 (He et al., 2015) and Tigriopus japonicus copepods exposed to $\mathrm{Cu}$ (Ki et al. 2009). Even though the current knowledge on the specific physiological roles of these proteins remains cryptic, their involvement in thiol/disulphide redox switches that modulate ion channel functioning, heme affinity and carbon monoxide metabolism appear consensual (Ragsdale and Yi, 2011). Moreover, different biological functions can be linked to this family of proteins across different clades of life, such as oxidative stress repair, apoptosis and immune response (Fortunato et al., 2016). Therefore, increased expression of Heme-bp suggests As induced stress response in C. gigas.

Arginine-tRNA-protein transferase 1 (Ate-1) expression levels were lower in C. gigas exposed to As in comparison to CTL (Table 2). Ate-1 mediates proteolysis by catalysing protein arginylation, a process involved in actin cytoskeleton regulation (Kashina, 2014). Additionally, Kumar et al. (2016) recently studied Ate- 1 and arginylation processes during stress response signalling towards oxidative, thermal, osmotic and metal stress. Among several findings, these authors suggested that Ate-1 depletion may increase cellular resistance to several stressors (e.g. $\mathrm{H}_{2} \mathrm{O}_{2}, \mathrm{CdCl}_{2}$, ultra violet radiation and others) and supress apoptosis (Kumar et al., 2016). Considering these findings, decreased abundance of Ate-1 in C. gigas exposed to As suggests increased stress resistance and apoptosis suppression. Interestingly, oysters exposed to the combination of Low $\mathrm{pH}+$ As did not present decreased Ate-1 levels, indicating either impairment of this process or a less deleterious oxidative status in C. gigas exposed to Low $\mathrm{pH}+$ As.

Significant differences were also observed between protein expression profiles of As exposed oysters compared to conditions other than CTL. Alpha-crystallin a chain ( $\alpha$-crystallin a), was significantly lower in As compared to Low $\mathrm{pH}$. This difference could be related to the dynamic expression of sHsps (Morrow and Tanguay, 2012) as discussed for $\alpha$ crystallin b in C. angulata (Section 3.4.1) and provide further evidence of concerted regulation of sHsps towards different types of stressors, and/or a evidencing a pro-apoptotic status as previously discussed.

Results also showed higher abundance of Aconitate hydratase (Achd) in C. gigas exposed to As in comparison to oysters exposed to Low $\mathrm{pH}$ (Table 2). This mitochondrial enzyme is an important player in the TCA cycle, and a potential oxidative stress biomarker (Bota et al., 2002). Khondee et al. (2016) also observed increased Achd abundance in C. gigas exposed to TBT and explained their results as a stimulation of the energy flow through the TCA cycle to fuel energetically demanding responses towards xenobiotic exposure. Because Achd is sensitive to oxidative stress (Cherkasov et al., 2007), its transcriptional upregulation has also been discussed as a compensation mechanism to counteract ROS-mediated self-inactivation in Argopecten irradians scallops under hypoxia (Ivanina et al., 2016). Hence, the present findings showing altered Achd abundance suggest relatively higher oxidative stress and increased energetic flow through the TCA cycle in $C$. gigas exposed to As compared to those exposed to Low $\mathrm{pH}$.

\subsubsection{Protein changes induced by Low $p H$}

C. gigas exposed to Low $\mathrm{pH}$ presented increased expression levels of Actin, Atlastin and Neprilysin in comparison to oysters from CTL (Table 2). Increased Actin levels in oysters (S. glomerata) exposed to 
acidification scenarios were described (Thompson et al., 2015, 2016), and discussed as a compensation mechanism to replace damaged proteins incurring oxidative damage. Actin, the predominant structural component of the cytoskeleton (Small, 1988) is among the most differentially expressed proteins in oyster species experiencing environmental stress (reviewed in Anderson et al., 2015). Hence, the present results show significantly higher abundance of Actin in oysters exposed to Low $\mathrm{pH}$ suggest cytoskeleton restructuring and a possible prooxidant status.

The present findings further revealed induction of Atlastin in $C$. gigas exposed to Low $\mathrm{pH}$ compared to unexposed oysters (CTL) (Table 2). Atlastin, has a role in shaping endoplasmic reticulum (ER) tubular network, by generating branched ER structures (Barlowe, 2009) and modulating proteoliposome/membrane fusion (Farhan and Hauri, 2009). The ER is key organelle in protein synthesis/folding, calcium storage, metabolism and many signalling processes (Görlach et al., 2006), but also a major source of reactive oxygen species (ROS) in invertebrates experiencing environmental stress (Tomanek, 2015). Therefore, the present results suggest reconfiguration of the ER by induction of Atlastin in oysters exposed to Low $\mathrm{pH}$, with likely implications in all the above-stated cellular processes and modulation of ROS production rates.

Neprilysin was also increased in C. gigas exposed to Low $\mathrm{pH}$ compared to CTL (Table 2). In invertebrates the biological roles of Neprilysin have been related to neural stimulation (Turner et al., 2001), regeneration capacity (Sarras et al., 2002), extracellular matrix breakdown, gelatinolytic and fibrinolytic activities (Domínguez-Pérez et al., 2018). Given this, the present findings indicate that Neprilysin participates in extracellular restructuring and dynamics in C. gigas exposed to Low $\mathrm{pH}$.

\subsubsection{Protein changes under Low $p H+A s$}

Atypical serine-protein kinase ATM (ATM_Hsap) expression levels were higher in Low $\mathrm{pH}+$ As compared to CTL (Table 2). Protein kinases are important enzymes involved in protein phosphorylation regulation necessary for cell signal transduction processes in response to external stimuli (Epelboin et al., 2016). The recent assessment of $C$. gigas kinome revealed that Atypical protein kinases are mobilized under different biological processes, namely during embryonic development and environmental stress (Epelboin et al., 2016). For instance, these authors described ATM_Hsap regulation during C. gigas embryogenesis suggesting a role in cell-cycle progression. Additionally, some kinases appear to respond to stress (e.g. thermal, osmotic, metal and aerial exposure); they include atypical kinases (SMG1_Hsap and TRRAP_Hsap) that are increased in response to Zn (Epelboin et al., 2016). The present data provide further evidence of the involvement of protein kinases in environmental stress response, namely increased ATM_Hsap expression in response to the combined effects of Low $\mathrm{pH}+$ As, but the physiological effects of differential ATM_Hsap expression remain to be investigated.

Abundance levels of aldehyde dehydrogenase (Aldh) were higher in Low $\mathrm{pH}+$ As than in Low $\mathrm{pH}$ condition (Table 2). Aldh is an enzyme involved in aldehyde detoxification, a biproduct of ROS interaction with polyunsaturated fatty acids (Singh et al., 2013). Hence Aldh is an important enzyme in the oxidative stress response, by mitigating deleterious effects of aldehyde formation in processes such as lipid peroxidation (Marchitti et al., 2008; Singh et al., 2013). Several studies have demonstrated increased Aldh expression in bivalve species in response to environmental stress, including $S$. cucculata exposed to TBT (Khondee et al., 2016) and M. galloprovincialis under thermal stress (Tomanek, 2012). Apart from aldehyde detoxification, another role of Aldh is to provide reducing equivalents (NADPH) to increase reactive oxygen species (ROS) scavenging capacity by the glutathione system (Tomanek, 2014, 2015). Therefore, the present findings showing higher Aldh levels in C. gigas exposed to Low $\mathrm{pH}+$ As in comparison to Low $\mathrm{pH}$, demonstrate that the combined exposure resulted in higher oxidative stress response in $C$. gigas.

Apart from differences in protein expression observed between Low $\mathrm{pH}+$ As and CTL, the present results also revealed differences in protein abundance profiles between stress conditions, namely Retinal dehydrogenase (Rdh) and Enolase (Table 2). Increased expression of Retinal dehydrogenase (Rdh) in C. gigas exposed to Low $\mathrm{pH}$ compared to Low $\mathrm{pH}+$ As was similar in C. angulata (previously described). These findings indicate that increased expression of Rdh could be a common mechanism in oyster species exposed to acidification, in line with results from Thompson et al. (2015), with likely physiological implications regarding tissue regeneration capacity (Albalat, 2009; GutierrezMazariegos et al., 2014). However, induction of this protein was not observed under the combined effects of Low $\mathrm{pH}+$ As, evidencing that the presence of both stressors induced a different response, possibly because Rdh is inhibited by metals (Luo et al., 2014; Meng et al., 2015; Bao et al., 2016).

C. gigas presented higher expression levels of Enolase in Low $\mathrm{pH}$ exposure compared to Low $\mathrm{pH}+$ As (Table 2). Other studies have described increased expression of Enolase in bivalves, such as Mytilus edulis under thermal stress (Péden et al., 2016) and S. cucculata exposed to TBT (Khondee et al., 2016). Glycolysis stimulation by Enolase has been discussed as a mechanism to increase carbohydrate metabolism in bivalves experiencing energetically demanding conditions (Tomanek, 2014; Artigaud et al., 2015). Considering the concept of energy-limiting stress tolerance proposed by Sokolova et al. (2012), and the present data showing strong intra- and extracellular restructuring (Actin, Atlastine and Neprilysin) as well as induced regeneration capacity (Rdh) in C. gigas exposed to Low $\mathrm{pH}$, it is likely that abundance levels of Enolase were increased to stimulate carbohydrate metabolism to fuel these energetically demanding stress responses. Significant differences of expression levels of Enolase between Low pH and Low pH + As only, indicate differences in energetic modulation in oysters exposed to single and combined exposures.

Other proteins, such as Actin, Atlastine, Neprilysin, Heme-bp, that were altered in single exposures (Low pH or As) were not altered in oysters exposed to the combination of both stressors (Table 2). Generally, none of these proteins presented changes in expression profiles in the combined exposure (Low $\mathrm{pH}+\mathrm{As}$ ), despite the observed changes in single exposures previously described, evidencing that the combined effects of different stressors induced a different proteomic response in C. gigas.

\subsection{Species comparison}

Both species presented differential expression of several proteins under As exposure, generally revealing a deleterious cellular status, but with different response patterns for each species. C. angulata showed cytoskeleton restructuring (Actin, Severin, Gelsolin), cellular redox imbalance (Lgl), inflammatory response and pro-apoptotic status (Pibf, $\alpha$-crystallin b), alterations in lipid metabolism (uncharacterized KIAA1109-like), and impairment of cell-cell adherence (ZO-1) processes. On the other hand, $C$. gigas exposed to As presented pro-oxidant status (Heme_bp) and development of anti-apoptotic mechanisms (Ate_1), oxidative stress response and higher metabolic demand (Achd). These differences could at least partially result from lower accumulated As concentrations observed in C. angulata than in C. gigas (Section 3.1), and together illustrate different capacities of each species to accumulate As and subsequently have different cellular responses towards it.

Overall, protein expression profiles revealed a different proteomic response of each species to Low $\mathrm{pH}$ exposure, although increased Rdh expression was common for both species exposed to acidification. Results obtained for $C$. angulata exposed to Low pH suggest metabolic depression (ATP $\beta$ ) and enhanced regeneration capacity (Rdh) towards CTL. Moreover, higher acid-base regulation (V-ATPase b) capacity, and tissue remodelling (Epend) potential were observed in comparison to Low $\mathrm{pH}+$ As. On the other hand, results obtained for $C$. gigas indicate 
major alterations of cellular and extracellular structure and dynamics (Actin, Atlastine, Neprilysin), as well as induction of Rdh. Additionally, increased carbohydrate metabolism (Enolase) in C. gigas exposed to Low $\mathrm{pH}$ compared to Low $\mathrm{pH}+$ As, highlight shifts in energetic efficiency to cope with multiple stressors. These findings highlight different metabolic strategies by each species to cope with seawater acidification. C. angulata presented supressed metabolism, while $C$. gigas increased energetic demand and concomitant carbohydrate metabolism stimulation to enable for cell and tissue remodulation.

Differentially expressed proteins identified in $C$. angulata exposed to Low $\mathrm{pH}+$ As indicate alterations in cytoskeleton structure (Actin, Coronin), metabolic depression (ATP $\beta$ ), increased protein turnover (Aminopeptidase) and homeostatic maintenance (Mycbp). Interestingly, several proteins that were differentially expressed in $C$. angulata exposed to single stressors (Low $\mathrm{pH}$ and As), showed overall lower change in expression levels in oysters exposed to Low $\mathrm{pH}+\mathrm{As}$ (e.g. ATP $\beta$, Rdh, Pibf, ZO-1, Epend-1, Gelsolin, Severin and Lgl). Overall these findings demonstrate a clear difference in cellular response of $C$. angulata to single or combined exposures to Low $\mathrm{pH}$ and As.

C. gigas exposed to Low $\mathrm{pH}+$ As presented increased kinase signalling (ATM_Hsap) compared to CTL, and enhanced antioxidant capacity (Aldh) compared to Low $\mathrm{pH}$. Moreover, several proteins that were altered in $C$. gigas exposed to single stressors (Low $\mathrm{pH}$ or As) did not present the same expression profiles in $C$. gigas exposed to Low $\mathrm{pH}+$ As (e.g. Rdh, Actin, Enolase, Neprilysin, Atlastin, Ate- 1 and Heme-bp) evidencing different response capacity in the presence of multiple stressors.

Overall, data on protein changes towards Low $\mathrm{pH}+$ As evidenced different responses by each species. The present results showing higher accumulation of As in $C$. gigas could partially explain these differences. Interestingly, decreased expression of piRNA in $C$. angulata suggested genome reconfiguration in response to Low $\mathrm{pH}+$ As (as opposed to $C$. gigas), possibly induced as an adaptive mechanism towards extreme stress. These data add to recent findings by Li et al. (2017) that showed higher phenotypic plasticity of $C$. angulata compared to $C$. gigas towards global warming and suggested higher adaptive potential of the former species under environmental change.

\section{Concluding remarks}

The results obtained in the present study gave a deeper insight into the modes of action of two closely related oyster species in responses towards the combined $\mathrm{OA}$ and As exposure. Arsenic accumulation analysis revealed no influence of acidification on As uptake by each species. However, C. gigas tended to accumulate higher As concentrations than $C$. angulata.

As a corollary, both species induced cellular remodelling in response to external stimuli, observed by altered levels cytoskeleton related proteins, namely Actin and Atlastine (C. gigas); Actin, Severin, Coronin and Gelsolin (C. angulata). However, the conditions at which each species presented such alterations differed, with $C$. gigas presenting altered cytoskeleton proteins in Low $\mathrm{pH}$ exposures, while $C$. angulata showed most alterations under both Arsenic exposures (As and Low $\mathrm{pH}+\mathrm{As})$.

Different metabolic strategies in response to environmental stimuli could explain some of the differences observed between species. For instance, metabolic suppression in C. angulata (decreased ATP $\beta$ ) in both Low $\mathrm{pH}$ and Low $\mathrm{pH}+$ As exposures, contrasted with results for $C$. gigas that suggested increased carbohydrate metabolism (Enolase and Achd) to sustain energetically challenging conditions (Low pH and As), and also highlight species specific response strategies towards different stressors.

Proteomic analysis of oysters exposed to the combined exposure to Low $\mathrm{pH}+$ As revealed important differences in oysters' response capacity compared to that observed in single exposures, corroborating the working hypothesis that multiple stressors will further challenge oyster species in the environment.

The variety of modes of action observed and discussed in the present study, provide a glimpse into the multitude of responses that enable these species to thrive in highly dynamic estuarine systems. However, the present results also illustrate marked differences in response signatures of each species to each condition. Ultimately, these differences may define competitive advantages in a changing environment, with likely implications for populations of both species worldwide.

\section{Acknowledgements}

This study was financially supported by the Portuguese Science Foundation (FCT) through CESAM (UID/AMB/50017) and CIMA (UID/ MAR/00350/2013) through FCT/MEC national funds and co-funded by FEDER within the PT2020 Partnership Agreement and Compete 2020. Anthony Moreira was supported by PhD grant no. SFRH/BD/93107/ 2013. Rosa Freitas was supported by a research position funded by the Integrated Programme of SR\&TD "Smart Valorization of Endogenous Marine Biological Resources Under a Changing Climate" (reference Centro-01-0145-FEDER-000018), co-funded by Centro 2020 program, Portugal 2020, European Union, through the European Regional Development Fund. The authors would like to acknowledge Mr. Pedro Ferreira from Exporsado for providing C. angulata specimens, as well as the aquaculture facility that provided $C$. gigas but preferred to remain anonymous.

\section{References}

Acunzo, J., Katsogiannou, M., Rocchi, P., 2012. Small heat shock proteins HSP27 (HspB1), $\alpha$ B-crystallin (HspB5) and HSP22 (HspB8) as regulators of cell death. Int. J. Biochem. Cell Biol. 44, 1622-1631. https://doi.org/10.1016/j.biocel.2012.04.002. Directed Issue: Small HSPs in Physiology and Pathology.

Albalat, R., 2009. The retinoic acid machinery in invertebrates: ancestral elements and vertebrate innovations. Mol. Cell. Endocrinol. 313, 23-35. https://doi.org/10.1016/ j.mce.2009.08.029.

Amaral, M.J., Costa, M.H., 1999. Macrobenthic communities of saltpans from the Sado estuary (Portugal). Acta Oecol. 20, 327-332. https://doi.org/10.1016/S1146-609X (99)00134-4.

Anderson, M., Gorley, R.N., Clarke, R.K., 2008. Permanova + for Primer: Guide to Software and Statisticl Methods.

Anderson, K., Taylor, D.A., Thompson, E.L., Melwani, A.R., Nair, S.V., Raftos, D.A., 2015 Meta-analysis of studies using suppression subtractive hybridization and microarrays to investigate the effects of environmental stress on gene transcription in oysters. PLoS One 10, e0118839. https://doi.org/10.1371/journal.pone.0118839.

Artigaud, S., Lacroix, C., Richard, J., Flye-Sainte-Marie, J., Bargelloni, L., Pichereau, V., 2015. Proteomic responses to hypoxia at different temperatures in the great scallop (Pecten maximus). PeerJ 3, e871. https://doi.org/10.7717/peerj.871.

Balassa, T., Berta, G., Jakab, L., Bohonyi, N., Szekeres-Bartho, J., 2018. The effect of the Progesterone-Induced Blocking Factor (PIBF) on E-cadherin expression, cell motility and invasion of primary tumour cell lines. J. Reprod. Immunol. 125, 8-15. https:// doi.org/10.1016/j.jri.2017.10.047.

Bao, Y., Liu, X., Zhang, W., Cao, J., Li, W., Li, C., Lin, Z., 2016. Identification of a regulation network in response to cadmium toxicity using blood clam Tegillarca granosa as model. Sci. Rep. 6, 35704. https://doi.org/10.1038/srep35704.

Barlowe, C., 2009. Atlasin GTPases shape up ER networks. Dev. Cell 17, 157-158. https:// doi.org/10.1016/j.devcel.2009.07.019.

Baumann, H., Smith, E.M., 2018. Quantifying metabolically driven $\mathrm{pH}$ and oxygen fluctuations in US nearshore habitats at diel to interannual time scales. Estuaries Coasts 41, 1102-1117. https://doi.org/10.1007/s12237-017-0321-3.

Birkenmeier, G., Stegemann, C., Hoffmann, R., Günther, R., Huse, K., Birkemeyer, C., 2010. Posttranslational modification of human glyoxalase 1 indicates redox-dependent regulation. PLoS One 5, e10399. https://doi.org/10.1371/journal.pone. 0010399.

Blum, H., Beier, H., Gross, H.J., 1987. Improved silver staining of plant proteins, RNA and DNA in polyacrylamide gels. Electrophoresis 8, 93-99.

Bota Daniela, A., Holly, Van Remmen, Davies Kelvin, J.A., 2002. Modulation of Lon protease activity and aconitase turnover during aging and oxidative stress. FEBS Lett. 532, 103-106. https://doi.org/10.1016/S0014-5793(02)03638-4.

Bradford, M.M., 1976. A rapid and sensitive method for the quantitation of microgram quantities of protein utilizing the principle of protein-dye binding. Anal. Biochem. 72, 248-254.

Brooks, D.R., Isaac, R.E., 2004. Nematode aminopeptidases. Aminopeptidases in Biology and Disease, Proteases in Biology and Disease. Springer, Boston, MA, pp. 309-329.

Buestel, D., Ropert, M., Prou, J., Goulletquer, P., 2009. History, status, and future of oyster culture in France. J. Shellfish Res. 28, 813-820.

Caldeira, K., Wickett, M.E., 2005. Ocean model predictions of chemistry changes from 
carbon dioxide emissions to the atmosphere and ocean. J. Geophys. Res. Oceans 110. Carlson, P., Van Beneden, R.J., 2014. Arsenic exposure alters expression of cell cycle and lipid metabolism genes in the liver of adult zebrafish (Danio rerio). Aquat. Toxicol. 153, 66-72. https://doi.org/10.1016/j.aquatox.2013.10.006. Proceedings from the 17th International Symposium on Pollutant Responses in Marine Organisms (PRIMO17)

Cherkasov, A.A., Overton, R.A., Sokolov, E.P., Sokolova, I.M., 2007. Temperature-dependent effects of cadmium and purine nucleotides on mitochondrial aconitase from a marine ectotherm, Crassostrea virginica: a role of temperature in oxidative stress and allosteric enzyme regulation. J. Exp. Biol. 210, 46-55. https://doi.org/10.1242/ jeb.02589.

Costa, P.M., Lobo, J., Caeiro, S., Martins, M., Ferreira, A.M., Caetano, M., Vale, C., DelValls, T.Á., Costa, M.H., 2008. Genotoxic damage in Solea senegalensis exposed to sediments from the Sado Estuary (Portugal): effects of metallic and organic contaminants. Mutat. Res. Genet. Toxicol. Environ. Mutagen. 654, 29-37. https://doi. org/10.1016/j.mrgentox.2008.04.007.

Costa, P.M., Diniz, M.S., Caeiro, S., Lobo, J., Martins, M., Ferreira, A.M., Caetano, M., Vale, C., DelValls, T.Á., Costa, M.H., 2009. Histological biomarkers in liver and gills of juvenile Solea senegalensis exposed to contaminated estuarine sediments: a weighted indices approach. Aquat. Toxicol. 92, 202-212. https://doi.org/10.1016/j. aquatox.2008.12.009.

Cross, I., Merlo, M.A., Rodríguez, M.E., Portela-Bens, S., Rebordinos, L., 2014. Adaptation to abiotic stress in the oyster Crassostrea angulata relays on genetic polymorphisms. Fish Shellfish Immunol. 41, 618-624. https://doi.org/10.1016/j.fsi.2014.10.011.

Dailianis, S., Patetsini, E., Kaloyianni, M., 2009. The role of signalling molecules on actin glutathionylation and protein carbonylation induced by cadmium in haemocytes of mussel Mytilus galloprovincialis (Lmk). J. Exp. Biol. 212, 3612-3620. https://doi. org/10.1242/jeb.030817.

De Gieter, M., Elskens, M., Baeyens, W., 2005. Fluxes and major transport routes of Arsenic in the Scheldt estuary. Mar. Chem. 95, 15-30. https://doi.org/10.1016/j. marchem.2004.06.012.

Dickson, A.G., 1990. Standard potential of the reaction: $\mathrm{AgCl}(\mathrm{s})+12 \mathrm{H} 2(\mathrm{~g})=\mathrm{Ag}(\mathrm{s})+$ $\mathrm{HCl}(\mathrm{aq})$, and and the standard acidity constant of the ion HSO4 - in synthetic sea water from 273.15 to $318.15 \mathrm{~K}$. J. Chem. Thermodyn. 22, 113-127. https://doi.org/ 10.1016/0021-9614(90)90074-Z.

Dickson, A.G., Millero, F.J., 1987. A comparison of the equilibrium constants for the dissociation of carbonic acid in seawater media. Deep Sea Res. Part A Oceanogr. Res. Pap. 34, 1733-1743. https://doi.org/10.1016/0198-0149(87)90021-5.

Dineshram, R., Wong, K.K.W., Xiao, S., Yu, Z., Qian, P.Y., Thiyagarajan, V., 2012. Analysis of Pacific oyster larval proteome and its response to high-CO2. Mar. Pollut. Bull 64, 2160-2167. https://doi.org/10.1016/j.marpolbul.2012.07.043.

Dineshram, R., Quan, Q., Sharma, R., Chandramouli, K., Yalamanchili, H.K., Chu, I., Thiyagarajan, V., 2015. Comparative and quantitative proteomics reveal the adaptive strategies of oyster larvae to ocean acidification. Proteomics 15, 4120-4134. https:// doi.org/10.1002/pmic.201500198.

Domínguez-Pérez, D., Campos, A., Alexei Rodríguez, A., Turkina, M.V., Ribeiro, T., Osorio, H., Vasconcelos, V., Antunes, A., 2018. Proteomic analyses of the unexplored sea Anemone Bunodactis verrucosa. Mar. Drugs 16. https://doi.org/10.3390/ md16020042.

Epelboin, Y., Quintric, L., Guévélou, E., Boudry, P., Pichereau, V., Corporeau, C., 2016. The kinome of Pacific Oyster Crassostrea gigas, its expression during development and in response to environmental factors. PLoS One 11, e0155435. https://doi.org/ 10.1371/journal.pone.0155435.

Ereira, T., Coelho, J.P., Duarte, A.C., Pardal, M.A., Pereira, M.E., 2015. Size-dependent arsenic accumulation in Scrobicularia plana in a temperate coastal lagoon (Ria De Aveiro, Portugal). Water Air Soil Pollut. 226, 1-7. https://doi.org/10.1007/s11270 015-2484-5.

Fabbri, E., Franzellitti, S., Valbonesi, P., 2008. HSP Expression in Bivalves.

Fabry, V.J., Seibel, B.A., Feely, R.A., Orr, J.C., 2008. Impacts of ocean acidification on marine fauna and ecosystem processes. ICES J. Mar. Sci. 65, 414-432. https://doi. org/10.1093/icesjms/fsn048.

Food and Agriculture Organization (FAO), 2015. World aquaculture production of fish, crustaceans, molluscs, etc., by principal species in 2013. Available at: fao.org/ fishery/docs/STAT/summary/a-6.pdf.

Farhan, H., Hauri, H.-P., 2009. Membrane biogenesis: networking at the ER with atlastin. Curr. Biol. 19, R906-R908. https://doi.org/10.1016/j.cub.2009.08.029.

Fortunato, A.E., Sordino, P., Andreakis, N., 2016. Evolution of the SOUL heme-binding protein superfamily across eukarya. J. Mol. Evol. 82, 279-290. https://doi.org/10. 1007/s00239-016-9745-9.

Freitas, R., Pires, A., Quintino, V., Rodrigues, A.M., Figueira, E., 2012. Subcellular partitioning of elements and availability for trophic transfer: Comparison between the Bivalve Cerastoderma edule and the Polychaete Diopatra neapolitana. Estuar. Coast. Shelf Sci. 99, 21-30. https://doi.org/10.1016/j.ecss.2011.11.039.

Freitas, R., Almeida, Â., Calisto, V., Velez, C., Moreira, A., Schneider, R.J., Esteves, V.I., Wrona, F.J., Figueira, E., Soares, A.M.V.M., 2016. The impacts of pharmaceutical drugs under ocean acidification: new data on single and combined long-term effects of carbamazepine on Scrobicularia plana. Sci. Total Environ. 541, 977-985. https:// doi.org/10.1016/j.scitotenv.2015.09.138.

Galloway, J.M., Swindles, G.T., Jamieson, H.E., Palmer, M., Parsons, M.B., Sanei, H., Macumber, A.L., Timothy Patterson, R., Falck, H., 2017. Organic matter control on the distribution of arsenic in lake sediments impacted by $\sim 65$ years of gold ore processing in subarctic Canada. Sci. Total Environ. 622-623, 1668-1679. https://doi. org /10.1016/j.scitotenv. 2017.10.048.

Görlach, A., Klappa, P., Kietzmann, T., 2006. The endoplasmic reticulum: folding, calcium homeostasis, signaling, and redox control. Antioxid. Redox Signal. 8, 1391-1418. https://doi.org/10.1089/ars.2006.8.1391.
Goulletquer, P., Wolowicz, M., Latala, A., Geairon, P., Huvet, A., Boudry, P., 1999. Comparative analysis of oxygen consumption rates between cupped oyster spat of Crassostrea gigas of French, Japanese, Spanish and Taiwanese origins. Aquat. Living Resour. 12, 271-277.

Grabowski, J.H., Brumbaugh, R.D., Conrad, R.F., Keeler, A.G., Opaluch, J.J., Peterson, C.H., Piehler, M.F., Powers, S.P., Smyth, A.R., 2012. Economic valuation of ecosystem services provided by oyster reefs. BioScience 62, 900-909. https://doi.org/10.1525/ bio.2012.62.10.10.

Gran, G., 1952. Determination of the equivalence point in potentiometric titrations. Part II. Analyst 77, 661-671. https://doi.org/10.1039/AN9527700661.

Guppy, M., Withers, P., 1999. Metabolic depression in animals: physiological perspectives and biochemical generalizations. Biol. Rev. Camb. Philos. Soc. 74, 1-40.

Gupta, S.C., Sharma, A., Mishra, M., Mishra, R.K., Chowdhuri, D.K., 2010. Heat shock proteins in toxicology: How close and how far? Life Sci. 86, 377-384. https://doi org/10.1016/j.lfs.2009.12.015.

Gutierrez-Mazariegos, J., Schubert, M., Laudet, V., 2014. Evolution of retinoic acid receptors and retinoic acid signaling. The Biochemistry of Retinoic Acid Receptors I Structure, Activation, and Function at the Molecular Level. Springer, pp. 55-73.

Harley, C.D.G., Randall Hughes, A., Hultgren, K.M., Miner, B.G., Sorte, C.J.B., Thornber, C.S., Rodriguez, L.F., Tomanek, L., Williams, S.L., 2006. The impacts of climate change in coastal marine systems. Ecol. Lett. 9, 228-241. https://doi.org/10.1111/j. 1461-0248.2005.00871.x.

Harney, E., Artigaud, S., Le Souchu, P., Miner, P., Corporeau, C., Essid, H., Pichereau, V., Nunes, F.L.D., 2016. Non-additive effects of ocean acidification in combination with warming on the larval proteome of the Pacific oyster, Crassostrea gigas. J. Proteom. Proteom. Evol. Ecol. 135, 151-161. https://doi.org/10.1016/j.jprot.2015.12.001.

He, Y., Jouaux, A., Ford, S.E., Lelong, C., Sourdaine, P., Mathieu, M., Guo, X., 2015. Transcriptome analysis reveals strong and complex antiviral response in a mollusc. Fish Shellfish Immunol. 46, 131-144. https://doi.org/10.1016/j.fsi.2015.05.023. SI Molluscan Immunity.

Henke, K., 2009. Arsenic: Environmental Chemistry, Health Threats and Waste Treatment. John Wiley \& Sons.

Heral, M., Deslous-Paoli, J.-M., Prou, J., 1986. Dynamiques des productions et des biomasses des huîtres creuses cultivées (Crassostrea angulata et Crassostrea gigas) dans le bassin de Marennes-Oléron depuis un siècle. CIEM Conseil International Pour l'Exploration de La Mer.

His, E., 1972. Premiers éléments de comparaison entre l'huître portugaise et l'huître japonaise. Science et Pêche 219, 1-9.

Hsiao, S.-T., Chuang, S.-C., Chen, K.-S., Ho, P.-H., Wu, C.-L., Chen, C.A., 2016. DNA barcoding reveals that the common cupped oyster in Taiwan is the Portuguese oyster Crassostrea angulata (Ostreoida; Ostreidae), not C. gigas. Sci. Rep. 6, 34057. https:// doi.org/10.1038/srep34057.

Hüning, A.K., Melzner, F., Thomsen, J., Gutowska, M.A., Krämer, L., Frickenhaus, S., Rosenstiel, P., Pörtner, H.-O., Philipp, E.E.R., Lucassen, M., 2013. Impacts of seawater acidification on mantle gene expression patterns of the Baltic Sea blue mussel: im plications for shell formation and energy metabolism. Mar. Biol. 160, 1845-1861. https://doi.org/10.1007/s00227-012-1930-9.

Ingham, P.W., Nakano, Y., Seger, C., 2011. Mechanisms and functions of Hedgehog sig nalling across the metazoa. Nat. Rev. Genet. 12, 393-406. https://doi.org/10.1038/ nrg2984.

IPCC, 2014. In: Core Writing Team, Pachauri, R.K., Meyer, L.A. (Eds.), Climate Change 2014: Synthesis Report. Contribution of Working Groups I, II and III to the Fifth Assessment Report of the Intergovernmental Panel on Climate Change. IPCC, Geneva, Switzerland, pp. 151.

Ivanina, A.V., Sokolova, I.M., 2013. Interactive effects of $\mathrm{pH}$ and metals on mitochondrial functions of intertidal bivalves Crassostrea virginica and Mercenaria mercenaria. Aquat. Toxicol. 144-145, 303-309. https://doi.org/10.1016/j.aquatox.2013.10.019.

Ivanina, A.V., Sokolova, I.M., 2015. Interactive effects of metal pollution and ocean acidification on physiology of marine organisms. Curr. Zool. 61, 653-668. https:// doi.org/10.1093/czoolo/61.4.653.

Ivanina, A.V., Nesmelova, I., Leamy, L., Sokolov, E.P., Sokolova, I.M., 2016. Intermittent hypoxia leads to functional reorganization of mitochondria and affects cellular bioenergetics in marine molluscs. J. Exp. Biol. 219, 1659-1674. https://doi.org/10. 1242/jeb.134700.

Iwasaki, Y.W., Siomi, M.C., Siomi, H., 2015. PIWI-interacting RNA: its biogenesis and functions. Annu. Rev. Biochem. 84, 405-433.

Kashina, A., 2014. Protein arginylation, a global biological regulator that targets actin cytoskeleton and the muscle. Anat. Rec. (Hoboken) 297, 1630-1636. https://doi.org/ $10.1002 /$ ar. 22969.

Khondee, P., Srisomsap, C., Chokchaichamnankit, D., Svasti, J., Simpson, R.J., Kingtong, S., 2016. Histopathological effect and stress response of mantle proteome following TBT exposure in the Hooded oyster Saccostrea cucullata. Environ. Pollut. 218, 855-862. https://doi.org/10.1016/j.envpol.2016.08.011.

Ki, J.-S., Raisuddin, S., Lee, K.-W., Hwang, D.-S., Han, J., Rhee, J.-S., Kim, I.-C., Park, H.G., Ryu, J.-C., Lee, J.-S., 2009. Gene expression profiling of copper-induced responses in the intertidal copepod Tigriopus japonicus using a $6 \mathrm{~K}$ oligochip microarray. Aquat. Toxicol. 93, 177-187. https://doi.org/10.1016/j.aquatox.2009.04.004.

Kohlmeyer, U., Kuballa, J., Jantzen, E., 2002. Simultaneous separation of 17 inorganic and organic arsenic compounds in marine biota by means of high-performance liquid chromatography/inductively coupled plasma mass spectrometry. Rapid Commun. Mass Spectrom. 16, 965-974. https://doi.org/10.1002/rcm.671.

Kumar, A., Birnbaum, M.D., Patel, D.M., Morgan, W.M., Singh, J., Barrientos, A., Zhang, F., 2016. Posttranslational arginylation enzyme Ate1 affects DNA mutagenesis by regulating stress response. Cell Death Dis. 7, e2378. https://doi.org/10.1038/cddis. 2016.284.

Kuo, M.T., Wei, Y., Yang, X., Tatebe, S., Liu, J., Troncoso, P., Sahin, A., Ro, J.Y., Hamilton, 
S.R., Savaraj, N., 2006. Association of fragile site-associated (FSA) gene expression with epithelial differentiation and tumor development. Biochem. Biophys. Res. Commun. 340, 887-893. https://doi.org/10.1016/j.bbrc.2005.12.088.

Laskarin, G., Tokmadzić, V.S., Strbo, N., Bogović, T., Szekeres-Bartho, J., Randić, L., Podack, E.R., Rukavina, D., 2002. Progesterone induced blocking factor (PIBF) mediates progesterone induced suppression of decidual lymphocyte cytotoxicity. Am. J. Reprod. Immunol. 48, 201-209.

Li, Y., Qin, J.G., Abbott, C.A., Li, X., Benkendorff, K., 2007. Synergistic impacts of heat shock and spawning on the physiology and immune health of Crassostrea gigas: an explanation for summer mortality in Pacific oysters. Am. J. Physiol. Regul. Integr. Comp. Physiol. 293, R2353-R2362. https://doi.org/10.1152/ajpregu.00463.2007.

Li, G.H., Shi, Y., Chen, Y., Sun, M., Sader, S., Maekawa, Y., Arab, S., Dawood, F., Chen, M., Couto, G.D., Liu, Y., Fukuoka, M., Yang, S., Shi, M.D., Kirshenbaum, L.A., McCulloch, C.A., Liu, P., 2009. Gelsolin Regulates Cardiac Remodeling After Myocardial Infarction Through DNase I-Mediated Apoptosis. Circ. Res. 104, 896-904. https:// doi.org/10.1161/CIRCRESAHA.108.172882.

Li, J., Zhang, Y., Zhang, Y., Xiang, Z., Tong, Y., Qu, F., Yu, Z., 2014. Genomic characterization and expression analysis of five novel IL-17 genes in the Pacific oyster, Crassostrea gigas. Fish Shellfish Immunol. 40, 455-465. https://doi.org/10.1016/j. fsi.2014.07.026.

Li, A., Li, L., Song, K., Wang, W., Zhang, G., 2017. Temperature, energy metabolism, and adaptive divergence in two oyster subspecies. Ecol. Evol. 7, 6151-6162. https://doi. org/10.1002/ece3.3085.

Lin, M.-C., Galletta, B.J., Sept, D., Cooper, J.A., 2010. Overlapping and distinct functions for cofilin, coronin and Aip1 in actin dynamics in vivo. J. Cell. Sci. 123, 1329-1342. https://doi.org/10.1242/jcs.065698.

Lin, C., Yao, E., Wang, K., Nozawa, Y., Shimizu, H., Johnson, J.R., Chen, J.-N., Krogan, N.J., Chuang, P.-T., 2014. Regulation of Sufu activity by p66 $\beta$ and Mycbp provides new insight into vertebrate Hedgehog signaling. Genes Dev. 28, 2547-2563. https:// doi.org/10.1101/gad.249425.114.

Liu, Z., Zhou, Z., Wang, L., Song, X., Chen, H., Wang, W., Liu, R., Wang, M., Wang, H., Song, L., 2015. The enkephalinergic nervous system and its immunomodulation on the developing immune system during the ontogenesis of oyster Crassostrea gigas. Fish Shellfish Immunol. 45, 250-259. https://doi.org/10.1016/j.fsi.2015.03.041.

Luo, S., Lu, J., 2017. Silencing of Transposable Elements by piRNAs in Drosophila: An Evolutionary Perspective. Genomics, Proteomics \& Bioinformatics. RNA Epigenet. 15, 164-176. https://doi.org/10.1016/j.gpb.2017.01.006. (I).

Luo, L., Ke, C., Guo, X., Shi, B., Huang, M., 2014. Metal accumulation and differentially expressed proteins in gill of oyster (Crassostrea hongkongensis) exposed to long-term heavy metal-contaminated estuary. Fish Shellfish Immunol. 38, 318-329. https://doi. $\operatorname{org} / 10.1016 /$ j.fsi.2014.03.029.

Malagoli, D., 2010. Cytokine network in invertebrates: the very next phase of comparative immunology. Invertebrate Surviv. J. 7, 146-148.

Mamindy-Pajany, Y., Hurel, C., Géret, F., Galgani, F., Battaglia-Brunet, F., Marmier, N., Roméo, M., 2013. Arsenic in marine sediments from French Mediterranean ports: geochemical partitioning, bioavailability and ecotoxicology. Chemosphere 90, 2730-2736. https://doi.org/10.1016/j.chemosphere.2012.11.056.

Mani, S.R., Juliano, C.E., 2013. Untangling the web: the diverse functions of the PIWI/ piRNA pathway. Mol. Reprod. Dev. 80, 632-664. https://doi.org/10.1002/mrd. 22195.

Marchitti, S.A., Brocker, C., Stagos, D., Vasiliou, V., 2008. Non-P450 aldehyde oxidizing enzymes: the aldehyde dehydrogenase superfamily. Expert Opin. Drug Metab. Toxicol. 4, 697-720. https://doi.org/10.1517/17425255.4.6.697.

Martin, M., Osborn, K.E., Billig, P., Glickstein, N., 1981. Toxicities of ten metals to Crassostrea gigas and Mytilus edulis embryos and Cancer magister larvae. Mar. Pollut. Bull. 12, 305-308. https://doi.org/10.1016/0025-326X(81)90081-3.

Martín-Torre, M.C., Cifrian, E., Ruiz, G., Galán, B., Viguri, J.R., 2017. Estuarine sediment resuspension and acidification: release behaviour of contaminants under different oxidation levels and acid sources. J. Environ. Manage. 199, 211-221. https://doi. org/10.1016/j.jenvman.2017.05.044.

Masson, M., Schäfer, J., Blanc, G., Pierre, A., 2007. Seasonal variations and annual fluxes of arsenic in the Garonne, Dordogne and Isle Rivers, France. Sci. Total Environ. 373, 196-207. https://doi.org/10.1016/j.scitotenv.2006.10.039.

Matoo, O.B., Ivanina, A.V., Ullstad, C., Beniash, E., Sokolova, I.M., 2013. Interactive effects of elevated temperature and $\mathrm{CO} 2$ levels on metabolism and oxidative stress in two common marine bivalves (Crassostrea virginica and Mercenaria mercenaria). Comp. Biochem. Physiol. Part A Mol. Integr. Physiol. 164, 545-553. https://doi.org/ 10.1016/j.cbpa.2012.12.025

McKay, R.M., McKay, J.P., Avery, L., Graff, J.M., 2003. C. elegans: a model for exploring the genetics of fat storage. Dev. Cell 4, 131-142. https://doi.org/10.1016/S15345807(02)00411-2.

Mehrbach, C., Culberson, C.H., Hawley, J.E., Pytkowicx, R.M., 1973. Measurement of the apparent dissociation constants of carbonic acid in seawater at atmospheric Pressure1. Limnol. Oceanogr. 18, 897-907. https://doi.org/10.4319/lo.1973.18.6. 0897.

Melwani, A.R., Thompson, E.L., Raftos, D.A., 2016. Differential proteomic response of Sydney rock oysters (Saccostrea glomerata) to prolonged environmental stress. Aquat. Toxicol. 173, 53-62. https://doi.org/10.1016/j.aquatox.2016.01.003.

Melzner, F., Thomsen, J., Koeve, W., Oschlies, A., Gutowska, M.A., Bange, H.W., Hansen, H.P., Körtzinger, A., 2012. Future ocean acidification will be amplified by hypoxia in coastal habitats. Mar. Biol. 160, 1875-1888. https://doi.org/10.1007/s00227-0121954-1.

Meng, X., Tian, X., Nie, G., Wang, J., Liu, M., Jiang, K., Wang, B., Guo, Q., Huang, J. Wang, L., 2015. The transcriptomic response to copper exposure in the digestive gland of Japanese scallops (Mizuhopecten yessoensis). Fish Shellfish Immunol. 46, 161-167. https://doi.org/10.1016/j.fsi.2015.05.022.
Miller, A.W., Reynolds, A.C., Sobrino, C., Riedel, G.F., 2009. Shellfish face Uncertain future in high $\mathrm{CO} 2$ world: influence of acidification on oyster larvae calcification and growth in estuaries. PLoS One 4, e5661. https://doi.org/10.1371/journal.pone. 0005661.

Moreira, A., Figueira, E., Soares, A.M.V.M., Freitas, R., 2016. The effects of arsenic and seawater acidification on antioxidant and biomineralization responses in two closely related Crassostrea species. Sci. Total Environ. 545-546, 569-581. https://doi.org/ 10.1016/j.scitotenv.2015.12.029.

Moreira, A., Figueira, E., Libralato, G., Soares, A.M.V.M., Guida, M., Freitas, R., 2018. Comparative sensitivity of Crassostrea angulata and Crassostrea gigas embryo-larval development to As under varying salinity and temperature. Mar. Environ. Res. https://doi.org/10.1016/j.marenvres.2018.06.003.

Morrow, G., Tanguay, R.M., 2012. Small heat shock protein expression and functions during development. Int. J. Biochem. Cell Biol. 44, 1613-1621. https://doi.org/10. 1016/j.biocel.2012.03.009. Directed Issue: Small HSPs in Physiology and Pathology.

Moya, A., Huisman, L., Ball, E.E., Hayward, D.C., Grasso, L.C., Chua, C.M., Woo, H.N., Gattuso, J.-P., Forêt, S., Miller, D.J., 2012. Whole transcriptome analysis of the coral Acropora millepora reveals complex responses to CO2-driven acidification during the initiation of calcification. Mol. Ecol. 21, 2440-2454. https://doi.org/10.1111/j. 1365-294X.2012.05554.x.

Muraeva, O.A., Maltseva, A.L., Mikhailova, N.A., Granovitch, A.I., 2016. Mechanisms of adaption to salinity stress in marine gastropods Littorina saxatilis: a proteomic analysis. Cell Tiss. Biol. 10, 160-169. https://doi.org/10.1134/S1990519X16020085.

Muralidharan, S., Thompson, E., Raftos, D., Birch, G., Haynes, P.A., 2012. Quantitative proteomics of heavy metal stress responses in Sydney rock oysters. Proteomics 12, 906-921. https://doi.org/10.1002/pmic.201100417.

Nardi, A., Mincarelli, L.F., Benedetti, M., Fattorini, D., d'Errico, G., Regoli, F., 2017. Indirect effects of climate changes on cadmium bioavailability and biological effects in the Mediterranean mussel Mytilus galloprovincialis. Chemosphere 169, 493-502. https://doi.org/10.1016/j.chemosphere.2016.11.093.

Niinemets, Ü., Kahru, A., Nõges, P., Tuvikene, A., Vasemägi, A., Mander, Ü., Nõges, T., 2017. Environmental feedbacks in temperate aquatic ecosystems under global change: why do we need to consider chemical stressors? Reg. Environ. Change 17, 2079-2096. https://doi.org/10.1007/s10113-017-1197-2.

Park, M.S., Kim, Y.D., Kim, B.-M., Kim, Y.-J., Kim, J.K., Rhee, J.-S., 2016. Effects of antifouling biocides on molecular and biochemical defense system in the Gill of the Pacific Oyster Crassostrea gigas. PLoS One 11, e0168978. https://doi.org/10.1371/ journal.pone.0168978.

Parker, L.M., Ross, P.M., O’Connor, W.A., Pörtner, H.O., Scanes, E., Wright, J.M., 2013. Predicting the response of molluscs to the impact of ocean acidification. Biol. (Basel) 2, 651-692. https://doi.org/10.3390/biology2020651.

Péden, R., Rocher, B., Chan, P., Vaudry, D., Poret, A., Olivier, S., Le Foll, F., Bultelle, F., 2016. Consequences of acclimation on the resistance to acute thermal stress: proteomic focus on mussels from pristine site. Mar. Environ. Res. 121, 64-73. https:// doi.org/10.1016/j.marenvres.2016.02.006. 18th International Symposium on Pollutant Responses in Marine Organisms (PRIMO18).

Piacentini, L., Fanti, L., Specchia, V., Bozzetti, M.P., Berloco, M., Palumbo, G., Pimpinelli, S., 2014. Transposons, environmental changes, and heritable induced phenotypic variability. Chromosoma 123, 345-354. https://doi.org/10.1007/s00412-014 0464-y.

Ragsdale, S.W., Yi, L., 2011. Thiol/Disulfide redox switches in the regulation of heme binding to proteins. Antioxid. Redox Signal. 14, 1039-1047. https://doi.org/10. 1089/ars.2010.3436.

Raven, J., Caldeira, K., Elderfield, H., Hoegh-Guldberg, O., Liss, P., Riebesell, U., Shepherd, J., Turley, C., Watson, A., 2005. Ocean acidification due to increasing atmospheric carbon dioxide. R. Soc.

Regoli, F., Giuliani, M.E., 2014. Oxidative pathways of chemical toxicity and oxidative stress biomarkers in marine organisms. Mar. Environ. Res. 93, 106-117.

Regoli, F., Hummel, H., Amiard-Triquet, C., Larroux, C., Sukhotin, A., 1998. Trace metals and variations of antioxidant enzymes in Arctic Bivalve populations. Arch. Environ. Contam. Toxicol. 35, 594-601. https://doi.org/10.1007/s002449900421.

Ringwood, A.H., Keppler, C.J., 2002. Water quality variation and clam growth: is $\mathrm{pH}$ really a non-issue in estuaries? Estuaries 25, 901-907. https://doi.org/10.1007/ BF02691338.

Robbins, L.L., Hansen, M.E., Kleypas, J.A., Meylan, S.C., 2010. CO2calc: A User-Friendly Seawater Carbon Calculator for Windows, Mac OS X, and iOS (iPhone) (USGS Numbered Series No. 2010-1280) Open-File Report U.S. Geological Survey, Reston, VA.

Roberts, D.A., Birchenough, S.N.R., Lewis, C., Sanders, M.B., Bolam, T., Sheahan, D., 2013. Ocean acidification increases the toxicity of contaminated sediments. Glob. Change Biol. 19, 340-351. https://doi.org/10.1111/gcb.12048.

Robins, P.E., Skov, M.W., Lewis, M.J., Giménez, L., Davies, A.G., Malham, S.K., Neill, S.P., McDonald, J.E., Whitton, T.A., Jackson, S.E., Jago, C.F., 2016. Impact of climate change on UK estuaries: a review of past trends and potential projections. Estuar. Coast. Shelf Sci. 169, 119-135. https://doi.org/10.1016/j.ecss.2015.12.016.

Ryan, C.P., Brownlie, J.C., Whyard, S., 2016. Hsp90 and physiological stress are linked to autonomous transposon mobility and heritable genetic change in nematodes. Genome Biol. Evol. 8, 3794-3805. https://doi.org/10.1093/gbe/evw284.

Rybakin, V., Clemen, C.S., 2005. Coronin proteins as multifunctional regulators of the cytoskeleton and membrane trafficking. Bioessays 27, 625-632. https://doi.org/10. 1002/bies.20235.

Sarras Jr., M.P., Yan, L., Leontovich, A., Zhang, J.S., 2002. Structure, expression, and developmental function of early divergent forms of metalloproteinases in Hydra. Cell Res. 12, 163-176. https://doi.org/10.1038/sj.cr.7290123.

Sherwood, C.L., Liguori, A.E., Olsen, C.E., Lantz, R.C., Burgess, J.L., Boitano, S., 2013 Arsenic compromises conducting airway epithelial barrier properties in primary 
mouse and immortalized human cell cultures. PLoS One 8, e82970. https://doi.org/ 10.1371/journal.pone.0082970.

Shevchenko, A., Tomas, H., Havlis, J., Olsen, J.V., Mann, M., 2006. In-gel digestion for mass spectrometric characterization of proteins and proteomes. Nat. Protoc. 1 2856-2860. https://doi.org/10.1038/nprot.2006.468.

Silacci, P., Mazzolai, L., Gauci, C., Stergiopulos, N., Yin, H.L., Hayoz, D., 2004. Gelsolin superfamily proteins: key regulators of cellular functions. CMLS Cell. Mol. Life Sci. 61, 2614-2623. https://doi.org/10.1007/s00018-004-4225-6.

Singh, S., Brocker, C., Koppaka, V., Chen, Y., Jackson, B.C., Matsumoto, A., Thompson, D.C., Vasiliou, V., 2013. Aldehyde dehydrogenases in cellular responses to oxidative/ electrophilicstress. Free Radic. Biol. Med. 56, 89-101. https://doi.org/10.1016/j freeradbiomed.2012.11.010.

Small, J.V., 1988. The actin cytoskeleton. Electron Microsc. Rev. 1, 155-174. https://doi. org/10.1016/S0892-0354(98)90010-7.

Smelkinson, M.G., 2017. The hedgehog signaling pathway emerges as a pathogenic target. J. Dev. Biol. 5. https://doi.org/10.3390/jdb5040014.

Sokolova, I.M., Frederich, M., Bagwe, R., Lannig, G., Sukhotin, A.A., 2012. Energy homeostasis as an integrative tool for assessing limits of environmental stress tolerance in aquatic invertebrates. Mar. Environ. Res. 79, 1-15. https://doi.org/10.1016/ j.marenvres.2012.04.003.

Soletchnik, P., Huvet, A., Le Moine, O., Razet, D., Geairon, P., Faury, N., Goulletquer, P., Boudry, P., 2002. A comparative field study of growth, survival and reproduction of Crassostrea gigas, C. angulata and their hybrids. Aquat. Living Resour. 15, 243-250. https://doi.org/10.1016/S0990-7440(02)01175-0.

Srivastava, R., Prasadareddy Kajuluri, L., Pathak, N., Gupta, C.M., Sahasrabuddhe, A.A., 2015. Oligomerization of coronin: implication on actin filament length in Leishmania. Cytoskeleton (Hoboken) 72, 621-632. https://doi.org/10.1002/cm. 21269.

Szekeres-Bartho, J., Polgar, B., Kozma, N., Miko, E., Par, G., Szereday, L., Barakonyi, A., Palkovics, T., Papp, O., Varga, P., 2005. Progesterone-dependent immunomodulation. Immunol. Pregnancy 89, 118-125. https://doi.org/10.1159/000087953.

Thompson, E.L., Taylor, D.A., Nair, S.V., Birch, G., Haynes, P.A., Raftos, D.A., 2012. Proteomic discovery of biomarkers of metal contamination in Sydney Rock oysters (Saccostrea glomerata). Aquat. Toxicol. 109, 202-212.

Thompson, E.L., O'Connor, W., Parker, L., Ross, P., Raftos, D.A., 2015. Differential proteomic responses of selectively bred and wild-type Sydney rock oyster populations exposed to elevated CO2. Mol. Ecol. 24, 1248-1262. https://doi.org/10.1111/mec 13111.

Thompson, E.L., Parker, L., Amaral, V., Bishop, M.J., O'Connor, W.A., Raftos, D.A., 2016. Wild populations of Sydney rock oysters differ in their proteomic responses to elevated carbon dioxide. Mar. Freshw. Res. 67, 1964-1972. https://doi.org/10.1071/ MF15320.

Tomanek, L., 2012. Environmental Proteomics of the Mussel Mytilus: Implications for Tolerance to Stress and Change in Limits of Biogeographic Ranges in Response to Climate Change. Integr. Comp. Biol. 52, 648-664. https://doi.org/10.1093/icb/ ics114.

Tomanek, L., 2014. Proteomics to study adaptations in marine organisms to environmental stress. J. Proteom. 105, 92-106. https://doi.org/10.1016/j.jprot.2014.04. 009. Special Issue: Proteomics of non-model organisms.

Tomanek, L., 2015. Proteomic responses to environmentally induced oxidative stress. J. Exp. Biol. 218, 1867-1879. https://doi.org/10.1242/jeb.116475.

Tomanek, L., Zuzow, M.J., Ivanina, A.V., Beniash, E., Sokolova, I.M., 2011. Proteomic response to elevated $P_{\mathrm{CO} 2}$ level in eastern oysters, Crassostrea virginica: evidence for oxidative stress. J. Exp. Biol. 214, 1836-1844. https://doi.org/10.1242/jeb.055475.

Tresguerres, M., 2016. Novel and potential physiological roles of vacuolar-type $\mathrm{H}$ +-ATPase in marine organisms. J. Exp. Biol. 219, 2088-2097. https://doi.org/10. 1242/jeb.128389.

Turner, A.J., Isaac, R.E., Coates, D., 2001. The neprilysin (NEP) family of zinc metalloendopeptidases: genomics and function. Bioessays 23, 261-269. https://doi.org/ 10.1002/1521-1878(200103)23:3 < 261::AID-BIES1036 > 3.0.CO;2-K.

Valette-Silver, N.J., Riedel, G.F., Crecelius, E.A., Windom, H., Smith, R.G., Dolvin, S.S 1999. Elevated arsenic concentrations in bivalves from the southeast coasts of the USA. Mar. Environ. Res. 48, 311-333. https://doi.org/10.1016/S0141-1136(99) 00057-4.

Wäge, J., Lerebours, A., Hardege, J.D., Rotchell, J.M., 2016. Exposure to low pH induces molecular level changes in the marine worm, Platynereis dumerilii. Ecotoxicol. Environ. Saf. 124, 105-110. https://doi.org/10.1016/j.ecoenv.2015.10.008.

Wang, X., Mu, X., Zhang, J., Huang, Q., Alamdar, A., Tian, M., Liu, L., Shen, H., 2015. Serum metabolomics reveals that arsenic exposure disrupted lipid and amino acid metabolism in rats: a step forward in understanding chronic arsenic toxicity. Metallomics 7, 544-552. https://doi.org/10.1039/c5mt00002e.

Young, S.L., Diolaiti, D., Conacci-Sorrell, M., Ruiz-Trillo, I., Eisenman, R.N., King, N., 2011. Premetazoan ancestry of the Myc-Max network. Mol. Biol. Evol. 28, 2961-2971. https://doi.org/10.1093/molbev/msr132.

Zeng, X., Chen, X., Zhuang, J., 2015. The positive relationship between ocean acidification and pollution. Mar. Pollut. Bull. 91, 14-21. https://doi.org/10.1016/j. marpolbul.2014.12.001

Zhang, W., Wang, W.-X., Zhang, L., 2013. Arsenic speciation and spatial and interspecies differences of metal concentrations in mollusks and crustaceans from a South Chin estuary. Ecotoxicology 22, 671-682. https://doi.org/10.1007/s10646-013-1059-8.

Zhang, W., Guo, Z., Zhou, Y., Liu, H., Zhang, L., 2015a. Biotransformation and detoxification of inorganic arsenic in Bombay oyster Saccostrea cucullata. Aquat. Toxicol. 158, 33-40. https://doi.org/10.1016/j.aquatox.2014.10.021.

Zhang, Y., Sun, J., Mu, H., Li, J., Zhang, Y., Xu, F., Xiang, Z., Qian, P.-Y., Qiu, J.-W., Yu, Z., 2015b. Proteomic basis of stress responses in the gills of the Pacific Oyster Crassostrea gigas. J. Proteome Res. 14, 304-317. https://doi.org/10.1021/ pr500940s.

Zhao, X., Yu, H., Kong, L., Li, Q., 2012. Transcriptomic responses to salinity stress in the Pacific oyster Crassostrea gigas. PLoS One 7, e46244. 